ANNUAL REPORT

DE9? 004195

September 1, 1990, through August ś1, 1991

Project Title:

Principal Investigator:

Co-Principal Investigator:

Project Monitor:
Recovery of Fine Coal from Waste Streams Using Advanced Column Flotation

\section{DE-FG20-90PC 90176}

J. G. Groppo, University of Kentucky,

Center for Applied Energy Research

B. K. Parekh, University of Kentucky,

Center for Applied Energy Research

Dr. Dan Banerjee, CRSC

\title{
ABSTRACT
}

The advanced flotation techniques, namely column flotation, have shown potential in obtaining a low ash, low pyritic sulfur fine size clean coal. The overall objective of this program is to evaluate applicability of an advanced flotation technique, 'Ken-Flote' column to recuver clean coal with minimum mineral matter content at greater than 90 percent combustible recovery from two Illinois preparation plant waste streams.

Column flotation tests were conducted on the flotation feed obtained from the KerrMcGee Galatia and Ziegler No. 26 plants using three different bubble-generating devices: sparger, gas saver and foam jet. Each of these devices was tested with three different frothers and various column-operating variables to provide maximum combustible recovery, minimum product ash and maximum pyrite rejection. For the Galatia slurry, the column provided a clean coal containing 5 percent ash, 0.48 percent pyritic eutfur at combustible recovery averaging 90 percent. In other words, about 90 percent ash and about 75 percent pyritic sulfur rejection were attained for the Galatia slurry. Pilot plant studies on this slurry basically obtained results similar to the laboratory studies. For the Ziegler No. 26, slurry column flotation provided a clean coal containing about 5 percent ash, 0.44 percent pyritic sulfur at more than 90 percent combustible recovery. The ash and pyrite sulfur rejection was about 85 percent and 65 percent, respectively.

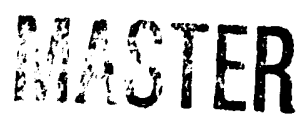

MFSTER

DSTHISTON OF THIS DOCUMENT IS UNLIMITED

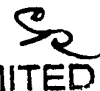

(This proiect is funded by the Illinois Department of Energy and Natural Resources as part of its cost-shared program with the U. S. Department of Energy.) 
Recovery oi fine coal is an important and integral part of coal pre jaration. However, currently available conventional flotation is inefficient for recovery of ultra-fine (minus 200 mesh) coal. Recent advances in flotation technology and reagent development have created new opportunities for recovery of low ash ultra-fine coals.

The primary objective of the present program is to evaluate applicability of the 'KenFlote' column flotation process developed at the University of Kentucky Center for Applied Energy Research for recovery of low ash, low pyritic sulfur clean coal from fine waste streams being produced at two different coal preparation plants (KerrMcGee, Galatia, and Ziegler No. 26) located in Illinois. These two preparation plants process high sulfur coals. The specific goals of the program are to maximize BTU recovery utilizing various column-operating parameters with particular emphasis on fine bubble-generating techniques and reagent packages to reject liberated ash and pyritic sulfur from the fine refuse stream.

The experimental program consisted of obtaining baseline flotation data using conventional flotation machine and a detailed column flotation testing using three different types of bubble-generating devices; i.e., sparger, gas saver and foam jet and three different types of frothers; i.e., methyl iso-butyl carbinol (MIBC). American Cyanamid AF76 and Betz M150. For the column flotation studies, fuel oil and frother dosages were kept constant at 1.5 pound/ton and 0.75 pound/ton, respectively. This amount was found to be optimum, as determined in batch flotation experiments.

For the Galatia slurry, the sparger provided satisfactory results with all the three frothers, providing about 90 percent combustible recovery. However, the ash content of clean coal was higher (11 percent) with M150 frother; whereas MIBC and AF-76 frothers provided a clean coal containing about 5.5 percent ash. Pyrite rejection* with MIBC and AF76 frother ranged from 65 to 75 percent; whereas with $M-150$ frother it was about 47 percent. Gas saver bubble-generating device worked satisfactorily only with N-150 frother giving about 90 percent combustible recovery, 5.7 percent ash in clean coal and 78 percent pyritic sulfur rejection. Foam jet bubble-generating device worked satisfactorily with all the three frothers, providing 90 percent combustible recovery, 5 percent ash in clean coal and rejection about 77 percent pyritic sulfur. Results obtained with the sparger and the foam jet were similar; however, the foam jet provided slightly better grade clean coal compared to sparger.

Pyrite Rejection $=(100-$ Yield $)$ 
All the tests conducted on the Kerr-McGee Galatia slurry indicated that, compared to conventional flotation, column flotation provided about 8 to 12 percent more combustible recovery, as well as provided clean coal containing about 5 percent ash, which is about 50 to 70 percent lower than conventional flotation.

For the Ziegler slurry, all the three bubble-generating devices and the frothers tested provided satisfactory results. Combustible recovery ranged from 85 to 95 percent, and the clean coal ash ranged from 4 to 7 percent. Pyrite rejection ranged from 50 to 67 percent. For this slurry, the best results were obtained with the $M-150$ and the foam jet, providing about 92 percent combustible recovery, 4.13 percent ash in clean coal and rejection about 65 percent of pyritic sulfur.

The pilot scale study conducted on the Galatia slurry provided a clean coal containing about 5.5 percent ash at about 75 to 80 percent combustible recovery. This batch of slurry sample had 60 percent ash compared to 40 percent ash obtained previously for laboratory studies.

Based on the results obtained in the present study, it is recommended that a demonstration column flotation unit capable of processing up to 100 gallons per minute of slurry be set up at the Ziegler No. 26 plant.

\section{DISCLAIMER}

This report was prepared as an account of work sponsored by an agency of the United States Teither the United States Government nor any agency thereof, nor any of their employees, makes any warranty, express or implied, or assumes any legal liability or responsibility for the accuracy, completeness, or usefulness of any information, apparatus, product, or process disclosed, or represents that its use would not infrirge privately owned rights. Reference herein to any specific commercial product, process, ot se-.ice by trade name, trademark, manufaciurer, or otherwise does not necessarily constitute or imply its endorsement, recommendation, or favoring by the United States Government or any agency thereof. The views and opinions of authors expressed herein do not necessarily state or reflect those of the Urited States Government or any agency thereof. 


\section{OBJECTIVES}

The main objective of the present research program is to evaluate applicability of the advanced column flotation, i.e., 'Ken-Flote' column, for recovery of clean coal from fine size refuse streams obtained from two different preparation plants located in the State of Illinois. It is also the objective of the program to optimize the column system with respect to the bubble-generation system and reagents to achieve 90 percent rejection of liberated ash and pyritic sulfur at a combustible recovery of more than 90 percent.

The above-stated objectives were achieved using four (4) different tasks. Task 1 involved acquisition and characterization of the fine refuse obtained from the KerrMcGee Company's Galatia plant and Ziegler No. 26. Task 2 consisted of obtaining baseline flotation data on reagents optimization using the conventional flotation machine. In Task 3, a detailed column flotation study was conducted on the two waste streams using various types of bubble-generating spargers and reagents. Task 4 involved pilot plant testing of the Galatic fine refuse stream. The objectives of the research programs were met using the above-stated tasks.

\section{INTRODUCTION AND BACKGROUND}

Cleaning of fine size coals to a very low mineral matter level would make coal more competitive with petroleum products, and would make a significant impact on marketability of the Illinois high sulfur coals. Most of the coal preparation plants generally discard the fine (minus 28 mesh) coal due to currently available inefficient and uneconomical conventional flotation process. These fine size refuse slurry are an excellent feed stock for producing low ash, low pyritic sulfur clean coal because the majority of the impurities are present in a free state. Thus, there is an incentive for the coal industry to recover this fine size coal using an economical and efficient process that will provide extra revenue for it, as well as provide a low mineral matter containing coal for use in advanced combustion applications.

Froth flotation techniques have been in use in mineral and coal beneficiation industries for many years. Studies on the fundamental aspect of coal flotation has been an ongoing process. Aplan' has summarized the effect of coal properties, reagents and process parameters for flctation of coal: Fuerstenau et $\mathrm{al}^{2}$ and $\mathrm{B}$. Morsi et $\mathrm{al}^{3}$ recently published a detailed study on characterization of coal surfaces as it relates to the froth flotation and oil agglomeration process.

In the last ten years, heavy emphasis has been placed on producing an ultraclean coal containing less than one percent ash and pyritic sulfur. Ash, being hydrophilic could be rejected in flotation; however, with ultrafine particle size, conventional flotation techniques may not be able to reject all of the liberated ash. Pyritic sulfur present in coal has an ambivalent hydrophobic/hydrophilic surface property; hence, its removal 
has ben reported to be difficult. Aplan et al. ${ }^{4.5}$ have summarized their research on evaluation of various pyrite depressants during flotation of coal. According to Aplan, a reagent found to be effective for depression of one coal-pyrite system was not effective for other coals. Kawatra ${ }^{6}$ reported removal of up to 85 percent pyritic sulfur from coal using the column flotation technique.

The column flotation technique has recently received wide attention in its ability to provide clean coal containing a low mineral matter at high combustible recovery. Yoon $^{7}$, Yang $^{8}$, and Christopherson ${ }^{9}$ have reported success in removal of a high amount of mineral matter from various fine coals. Parekh et al ${ }^{10,11}$ have reported that using their 'Ken-Flote' column up to 95 percent of pyritic sulfur was rejected from the Upper Freeport coal. They also reported that rejection of pyrite from freshly ground coal was more effective than 'aged' ground slurry.

There is strong evidence in literature that ash and pyritic sulfur, if present in the liberated state in coal, could be rejected using the column flotation technique without the use of any depressant. However, various columns being marketed in the U.S. differ in the bubble-generation system. The present project conducted a detailed evaluation of various types of bubble-generators and frothers for recovery of clean coal from the fine waste refuse slurry obtained from the : No Illinois preparation plants. This final annual report summarizes results and the conclusion of the project and offers recommendation for conducting a large: scale demonstration project.

\section{EXPERIMENTAL PROCEDURES}

Samples of the fine waste stream from the Galatia and Ziegler No. 26 were collected in clear-plastic-lined, 55-gallon drums. Representative samples of the slurries were analyzed for percent solids, $\mathrm{pH}$ and proximate analyses. Particle-size distribution of the solids was measured using the Granulometer, which utilizes the laser-scattering principle to determine the particle size.

Baseline flotation tests were conducted using a laboratory Denver flotation machine, Model D-12. For each test, two liters of the slurry were used, and rpm of the machine was fixed at 1200 . The slurry was conditioned for one minute after the addition of fuel oil and thirty seconds after the addition of frother. All the froth and tailings were analyzed using the standard ASTM procedures.

For the column flotation studies, a 2-inch ID, 20-foot long 'Ken-Flote' column was used. Figure 1 shows a line diagram of the column. Figure 2 shows the three different types of bubble-generating devices used for the research program. The sparger was mounted inside the column and required only addition of high pressure (40 psi g) air. The gas saver was mounted externally and a mixture of air and reagentized water was forced through it. The 'foam jet' was mounted internally, and a 


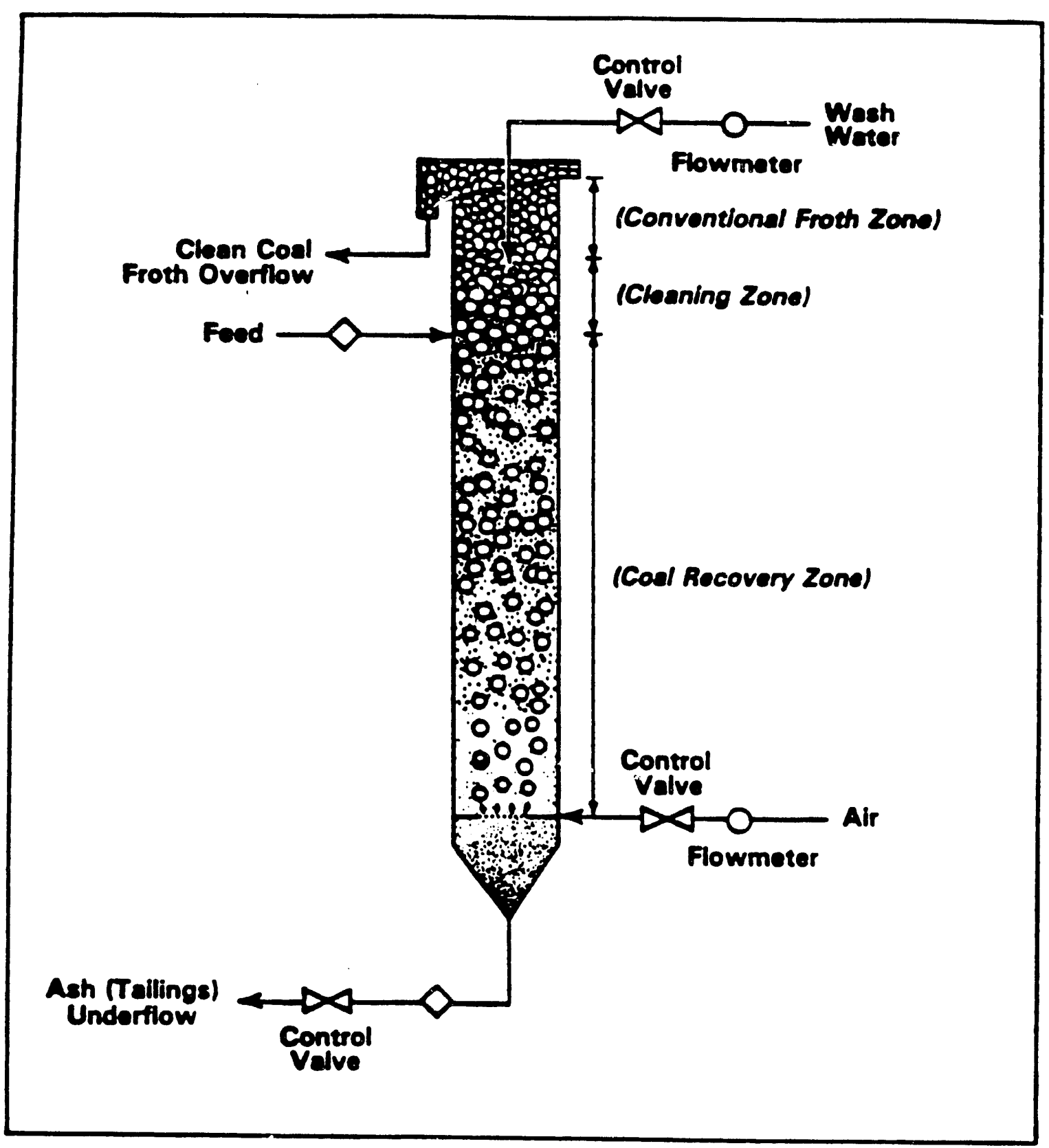

Figuro 1. Line Diagram of the 'Ken-Flote' Column Flotation Cell 

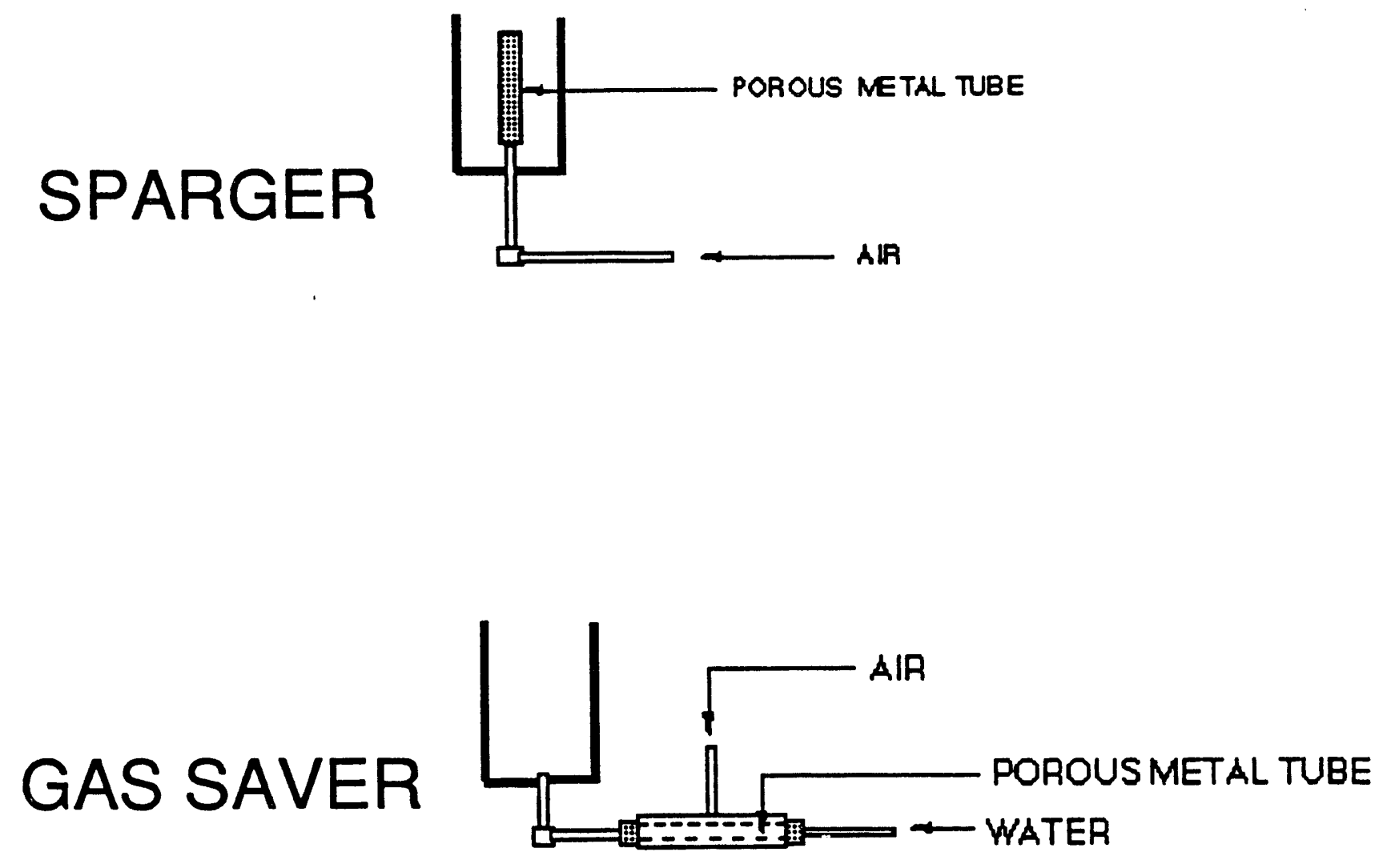

FOAM JET

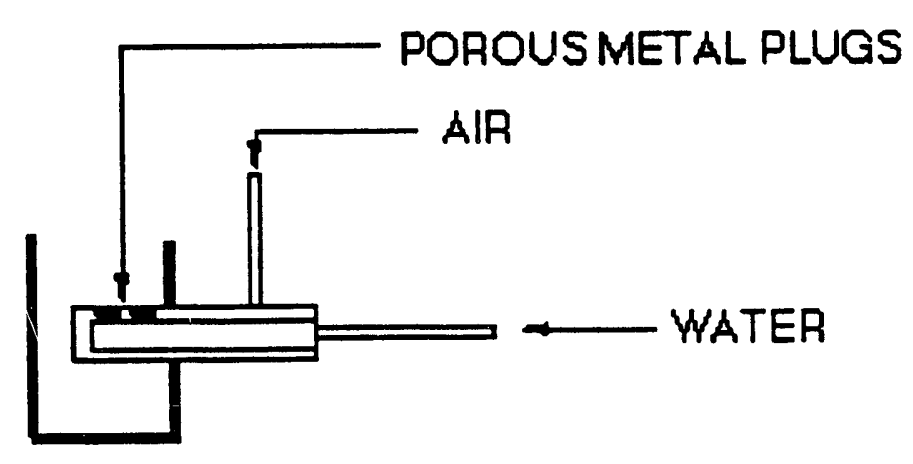

Figure 2. Diagrams of the Three Bubble-Generating Devices Utilized in Column Flotation Testing 
mixture of air and reagentized water was forced through a specially designed nozzle to generate bubbles.

The three different types of frothers used in the study and their supplier are listed below:

MIBC: Straight chain alcohol (Shell Oil Company)

AF76: $\quad$ Mixed alcohols (American Cyanamid Company)

M150: $\quad$ Glycol-based (Bet Chemical Company

For the column tests, emulsified reagents (oil in water) were added 'on line' to the system. For each test, the samples of froth and tailings were collected 20 minutes after the start of the experiment, which provided more than two times the retention time of slurry in the column.

\section{RESULTS AND DISCUSSIONS}

\section{Kerr-McGee - Galatia}

\section{Characterization of Flotation Feed Slurry}

The analyses of the Galatia flotation feed are summarized in Table 1, the slurry contained 3.5 percent solids and had a pH of 7.71. The average particle size determined with a Cilas Granulometre, Model 715, was 21.4 microns. The size and ash distribution of the solids in the flotation feed were determined by wet screen analysis and are also presented in Table 1 . The wet screen analysis indicated that 67.0 weight percent of the feed was finer than 500 mesh, and this fraction contained 91.1 percent of the total ash present.

A representative sample of the feed solids was submitted for pyrite size distribution using the optical microscopy technique. Figure 3 shows the pyrite size distribution in the free and included or "locked" states in the coal matrix. Note that over 90 percent of the pyrite present is finer than 5 microns, with nearly 70 percent of the total pyrite existing as free particles in this size fraction. Based on this information, it is apparent that a substantial quantity of pyrite may be rejected using froth flotation because it is present as frep particles.

\section{Baseline Flotation Data}

The baseline flotation data was obtained using a laboratory Denver Model D-12 batch flotation machine. Using frother (MIBC) alone provided 43 to 64 percent combustible recovery, with a clean coal ash of 15.7 to 12.5 percent ash. Optimum MIBC dosage was found to be 0.75 pound/ton. The addition of 1.5 pound/ton fuel oil improved combustible recovery to 83 percent while improving clean coal ash to 10 percent ash. 
Table 1. Analysis of Kerr-McGee Galatia Flotation Feed

\begin{tabular}{|c|c|c|c|}
\hline & $\begin{array}{l}\text { Weight } \\
\text { Percent }\end{array}$ & $\begin{array}{l}\text { Percent } \\
\text { Ash }\end{array}$ & $\begin{array}{l}\text { Ash } \\
\text { Distribution }\end{array}$ \\
\hline $\begin{array}{r}+200 \\
-200 \times 325 \\
-325 \times 500 \\
-500 \\
\text { Calc. Feed }\end{array}$ & $\begin{array}{r}15.2 \\
9.4 \\
8.4 \\
67.0 \\
100.0\end{array}$ & $\begin{array}{r}7.00 \\
13.10 \\
17.45 \\
\frac{56.66}{(41.72)}\end{array}$ & $\begin{array}{r}2.5 \\
2.9 \\
3.5 \\
91.1 \\
100.0\end{array}$ \\
\hline & $\begin{array}{l}\text { Percent Ash } \\
\text { Vol } \\
\text { FC } \\
\text { BTU } \\
\text { CI } \\
\text { S } \\
\text { S (pyrite) } \\
\text { S (sulfate) } \\
\text { S (organic) }\end{array}$ & $\begin{array}{c}41.07 \\
21.6 \\
35.0 \\
7520 \\
0.31 \\
2.06 \\
1.16 \\
0.04 \\
0.86\end{array}$ & \\
\hline
\end{tabular}




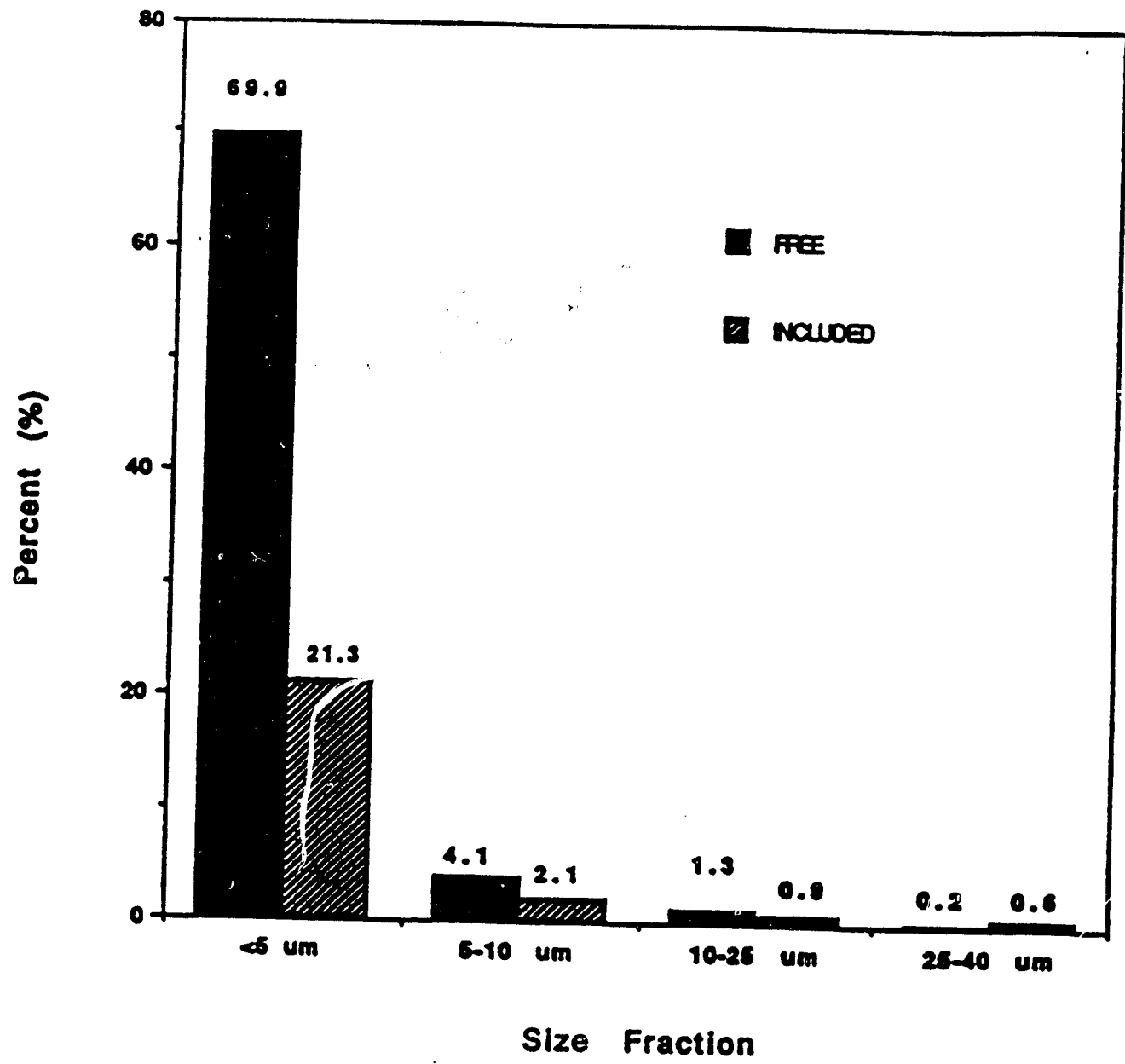

Figure 3. Size Distribution of Pyrite in the Galatia Flotation Feed 
The results obtained in baseline flotation testing using 0.75 pound/ton MIBC and 1.5 pound/ton fuel oil were consistent with typical operating results at the Galatia preparation plant.

Flotation tests were also conducted using two ash depressants (sodium silicate and phenylenediamine). For these tests, the reagent dosages were maintained at 0.75 pound/ton MIBC and 1.5 pound/ton fuel oil. No significant improvements in clean coal ash or ash rejection were apparent at depressant dosages as high as 5.0 pound/ton. Results obtained using a pyrite depressant $(\mathrm{WH}-1)$ showed that pyrite rejection improved from 28 to 37 percent when 5.0 pound/ton WH-1 was used; however, combustible recovery decreased from 87 to 80 percent over the same dosage range, suggesting that the pyrite depressant also depressed flotation of coal.

\section{Flotation Data Using Various Frothers:}

The results of flotation tests using three frothers are shown in Figure 4. The frother dosage was maintained at 0.7 pound/ton while the fuel oil dosage was varied. The data shows that recovery was significantly improved by the addition of fuel oil when MIBC was used as the frother; recovery improved from 53 percent to 87 percent by using 2.2 pound/ton fuel oil. Aerofroth76 (AF76) was a more powerful frother, providing 80 percent recovery with no fuel oil; recovery improved to 80 percent when 2.2 pound/ton fuel sil was used. The most powerful of the three frothers was Betz M150, which gave 87 percent recovery when used alone. A maximum recovery of 94 percent was achioved when 2.2 pound/ton of fuel oil was used.

Ash content of clean coal was lowered by the addition of fuel oil when using both MIBC and AF76. The lowest ash product obtained using MIBC was 10.8 percent ash, with a fuel oil dosage of 0.7 pound/ton. For AF76, the lowest ash content of the froth was 13.6 percent, which remained unchanged at fuel oil dosages of 0.7 to 2.2 pound/ton. When M150 was used, the ash content of the froth remained essentially unchanged (17.5 percent ash), even when fuel oil was added. The large volume of froth produced by this frother entrained a significant amount of ash into the froth product.

The effect of $\mathrm{pH}$ on the flotation of the coal using the three frother types is shown in Figure 5. To conduct these tests, the frother dosage was maintained at 0.75 pound/ton while the fuel oil dosage was 1.5 pound/ton. The results show that the optimum recovery was obtained near $\mathrm{pH} 6$ for MIBC (83 percent recovery) and AF76 (85.5 percent recovery). Recovery was diminished for both frothers when the $\mathrm{pH}$ was acidic (<pH5) and basic (>pH8). Recovery with M150 remained unchanged (85 to 91 percent recovery) throughout the $\mathrm{pH}$ range tested.

With the increase in the $\mathrm{pH}$ from 2.2 to 10.5 , the clean coal ash obtained using MIBC increased from 12.5 to 15.5 percent; and with AF76, the ash increased from 14.2 to 16.3 percent. With $\mathrm{M} 150$, the clean coal ash increased from 14.0 to a maximum of 16.8 as the $\mathrm{pH}$ increased from $\mathrm{pH} 2.2$ to 7 . These results suggest that more acidic 


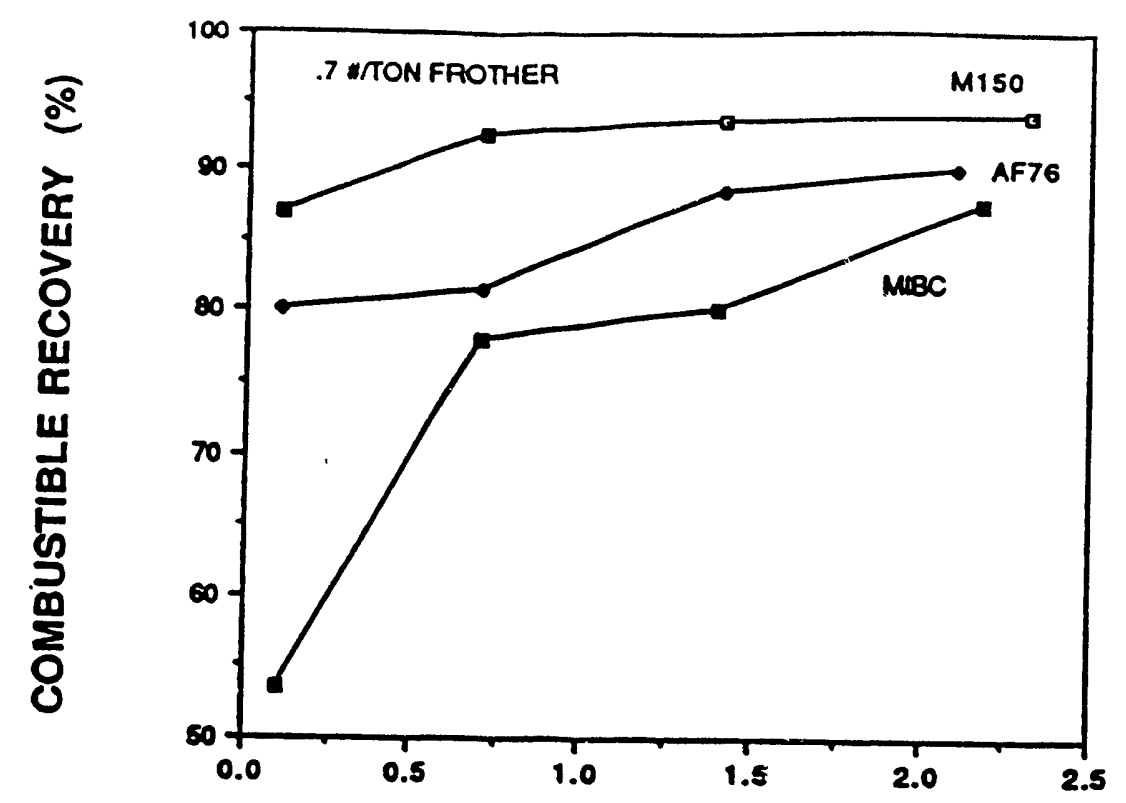

FUEL OIL DOSAGE (\#/TON)

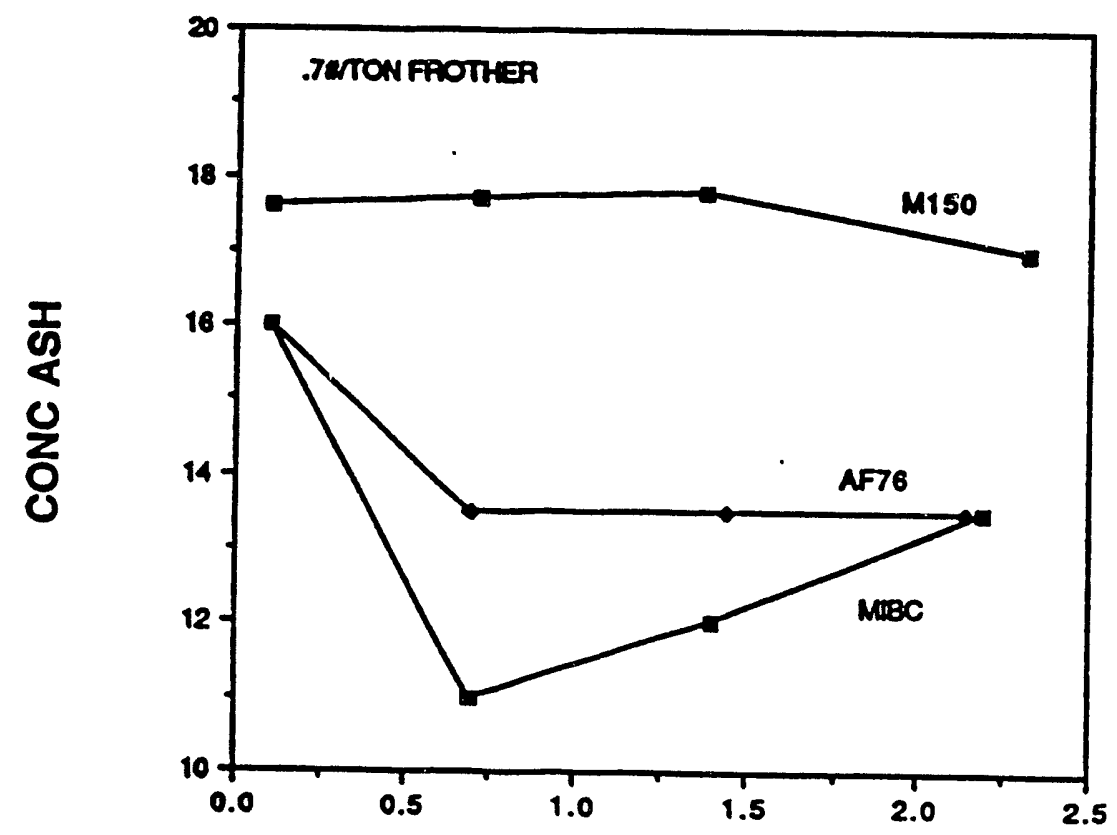

FUEL OIL DOSAGE (\#/TON)

Figure 4. Effect of Fuel Oil Dosage and Frother Type on Combustible Recovery and Ash Content of Clean Coal for Galatia Slurry 

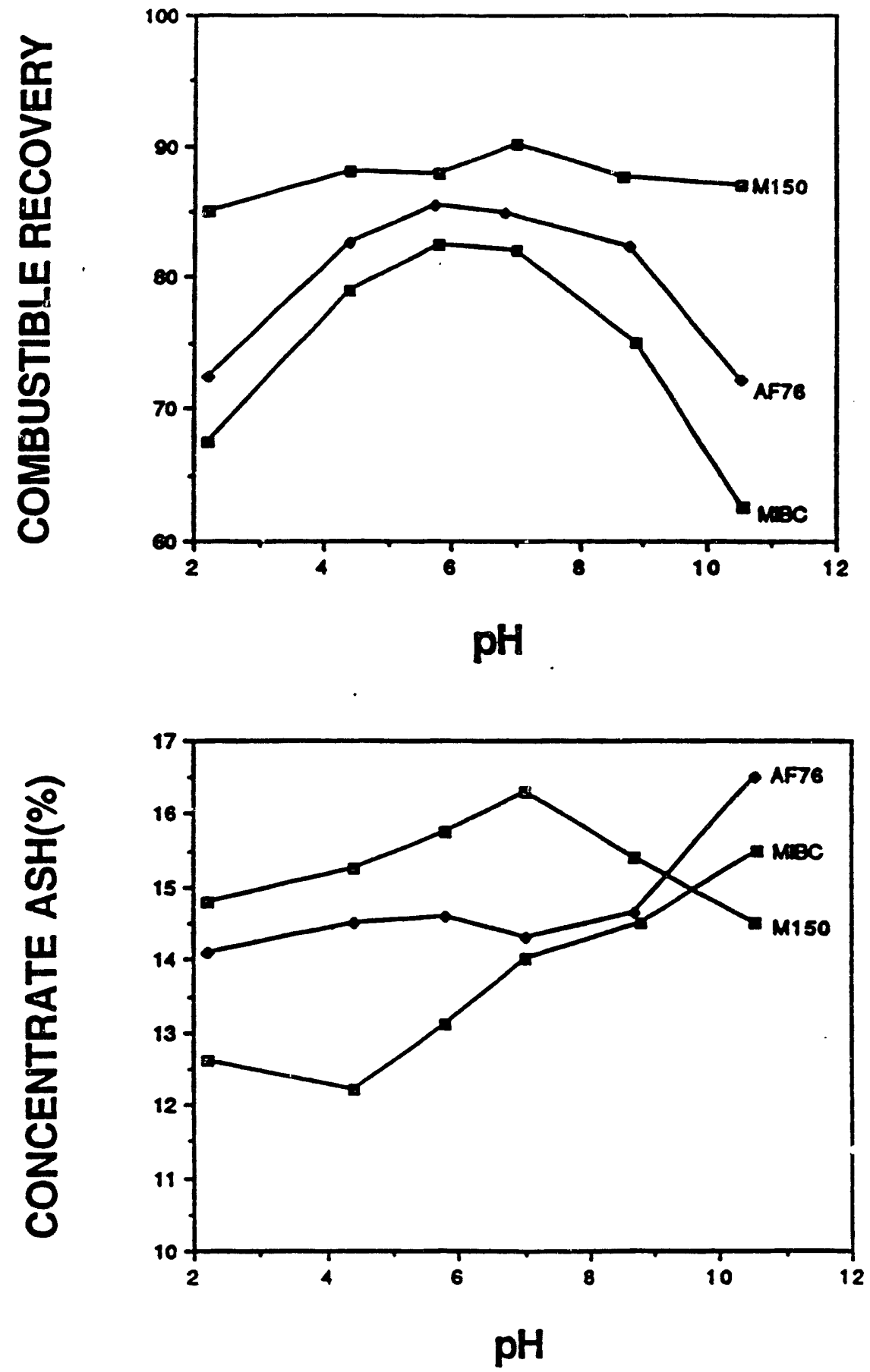

Figure 5. Effect of pH and Frother Type on Combustible Recovery and Ash Content of Clean coal for the Galatia Slurry 
$\mathrm{pH}$ provides lower ash content in the froth. As the $\mathrm{pH}$ is increased, clean coal ash also in ureases, possibly due to increased dispersion of ash particles at high $\mathrm{pH}$ values.

\section{Column Flotation Tests}

The results of column flotation tests conducted on the Galatia slurry with three frothers and three bubble-generating systems are presented in Appendix $A$. The best results obtained with MIBC for each of the bubble-generating devices are summarized in Figure 5. The sparger provided 91.4 percent combustible recovery, 5.97 percent clean coal ash and 66.8 percent pyrite rejection when $0.2 \mathrm{lpm}$ (lit/min.) wash water and $1.0 \mathrm{lpm}$ (lit/min.) airflow were used. Pyrite rejection improved to 76.3 percent when the foam jet was used for bubble generation; combustible recovery was 88.4 percent, while clean coal ash improved to 5.10 percent ash. MIBC was not suitable for use with the gas saver (64.9 percent combustible recovery and 3.66 percent clean coal ash). No pyrite analyses were completed for this test because the combustible recovery was poor.

Results obtained using Aerofroth 76 and the bubble-generating devices are summarized in Figure 7. When the sparger was used with $1 \mathrm{lpm}$ aiflow and $0.6 \mathrm{lpm}$ wash water, combustible recovery was 89.9 percent, with 5.25 percent clean coal ash and 75.8 percent pyrite rejection. The foam jet provided slightly higher combustible recovery (91.3 percent), with similar clean coal ash (5.20 percent ash) and pyrite rejection (75.5 percent). Optimum airflow requirement for the foam jet with AF76 was $3 \mathrm{lpm}$, while optimum wash water was $0.2 \mathrm{lpm}$. As with MIBC, AF76 was not a suitable frother for use with the gas saver. It provided only 47.2 percent combustible recovery.

All three bubble-generating devices provided excellent flotation results with M150 frother, as shown in Figure 8. The sparger provided 88.6 percent combustible recovery, 6.21 percent clean coal ash and 64.8 percent pyrite rejection. With the gas saver, combustible recovery improved to 91.0 percent; clean cal ash was reduced to 5.68 percent and pyrite rejection improved to 72.5 percent. The best results were obtained with the foam jet, which provided 90.1 percent combustible recovery, 4.80 percent ash in the clean cal and 76.9 percent pyrite rejection.

To summarize, the best results obtained in column flotation with the Galatia slurry were obtained using a foam jet bubble-generating device utilizing 0.75 pound/ton M150, 1.5 pound/ton fuel oil, $2 \mathrm{ipm}$ aifflow rate and $0.4 \mathrm{lpm}$ wash water rate. These conditions provided 90.1 percent combustible recovery, 4.80 percent clean coal ash and 76.9 percent pyrite rejection. When pyrite depressant $\mathrm{WH}-1$ was used with these column operating parameters, pyrite rejection improved to 80.0 percent, with 2.5 pound/ton WH-1; however, combustible recovery decreased to 78.1 percent, indicating that improvement in pyrite rejection with this depressant may be due to depression of coal. 


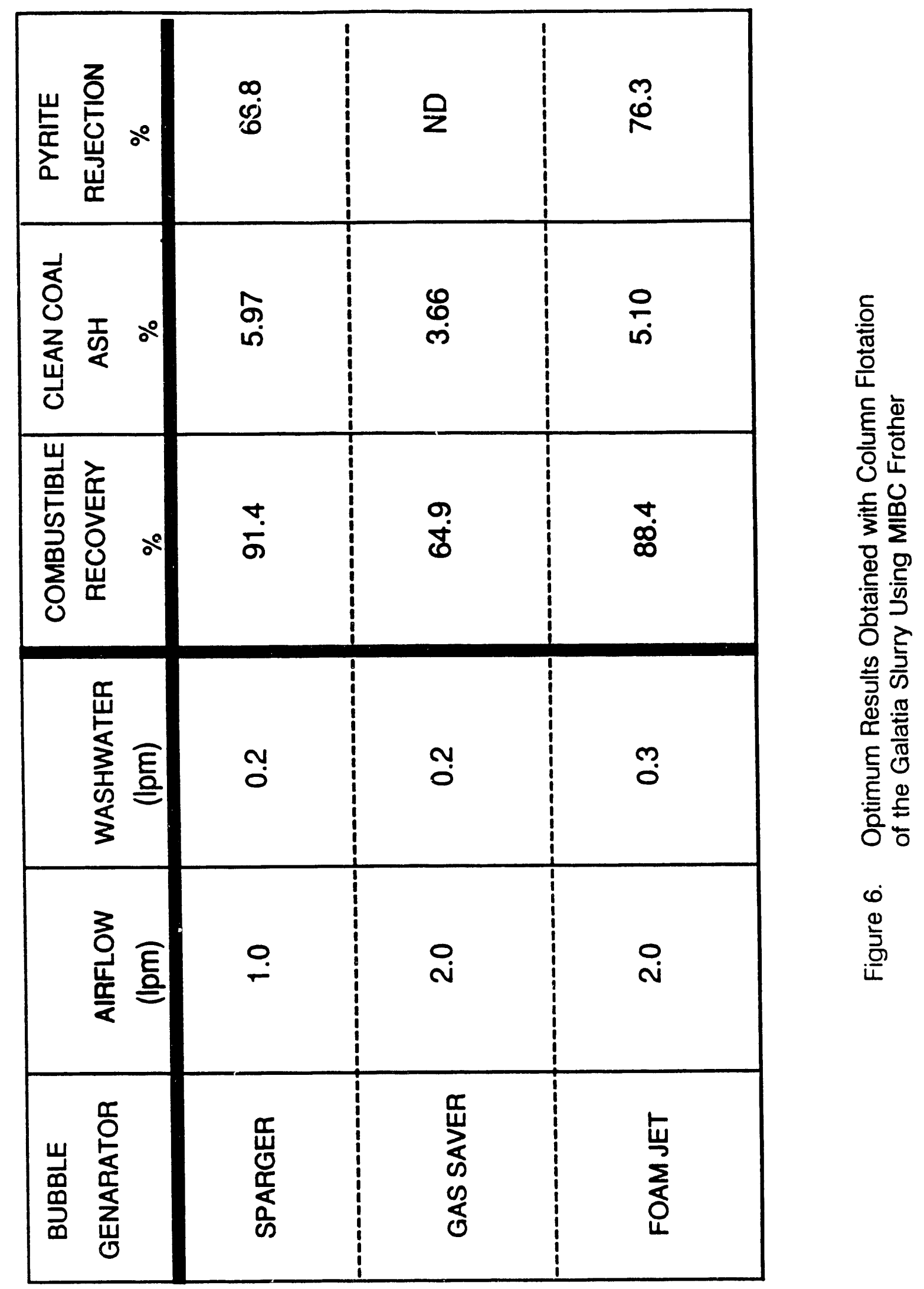




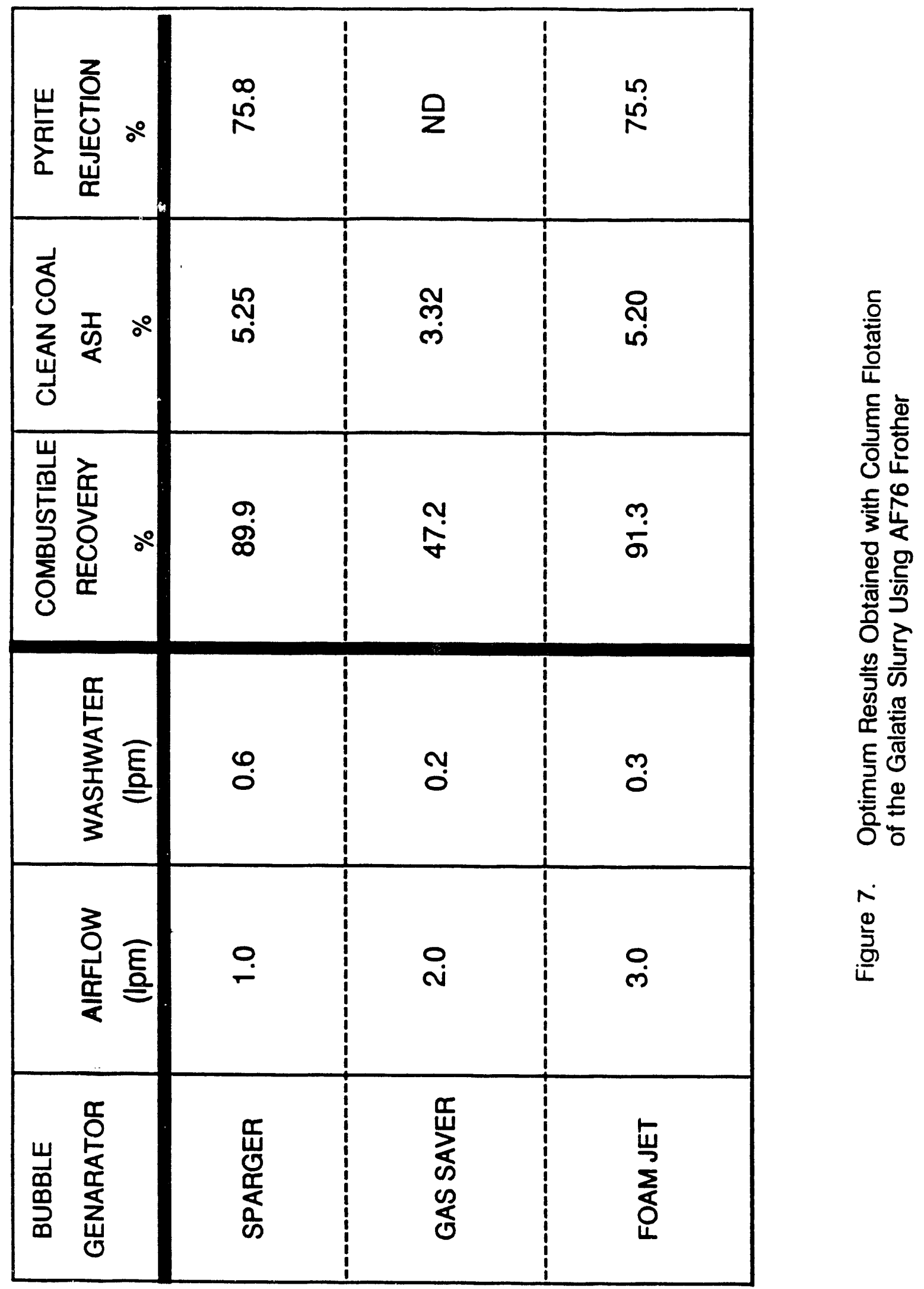




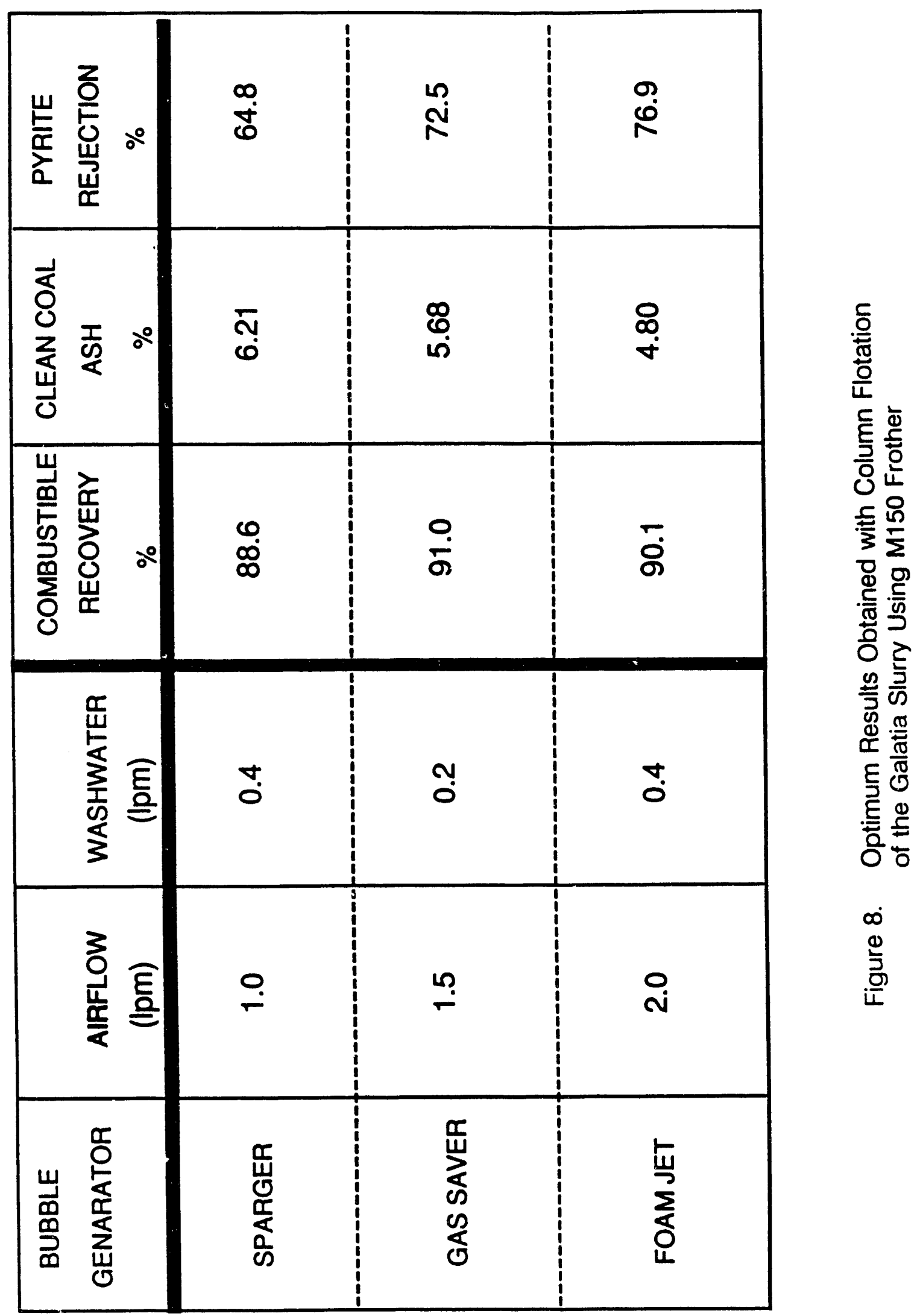


Ziegler No. 26

\section{Characterization of Flotation Feed Slurry}

The Ziegler No. 26 preparation plant in Sesser, llinois, employs conventional flotation of the $28 \times 200$ mesh solids thickened to 20 percent solids. To obtain this slurry, a classifying thickener is utilized with the overflow (-200 mesh) reporting to the refuse thickener, resulting in a total loss of all coal present in the -200 mesh fraction.

Samples were obtained from the classifying thickener overflow containing the minus 200 mesh material to determine if a clean coal product could be obtained with 90 percent combustible recovery and minimum clean coal ash. Analyses of the slurry presented in Table 2 show that the slurry contained 1.55 percent solids, with a natural $\mathrm{pH}$ of 7.78. The average particle size was 18.4 microns, as determined with a Cilas Granulometer Model 715. The size and ash distribution were determined by wet sieve analysis and are also presented in Table 2. Nearly 70 percent of the solids present was finer than 500 mesh, and this size fraction contained 93.1 percent of the total ash present.

A representative sample of the feed solids was submitted for pyrite size distribution using optical microscopy. Figure 9 shows the pyrite size distribution in the free and included or "locked" states in the coal matrix. Note that 93.7 percent of the pyrite was finer than 5 microns, with 77.9 percent of the total pyrite existing as free particles in. this size fraction. This indicates that a substantial quantity of pyrite may be rejected using froth flotation because it is present as free particles.

\section{Baseline Flotation Data}

The baseline flotation data was obtained using a laboratory Denver Model D-12 batch flotation machine. Optimum frother dosage for all three frothers was determined to be 1.5 pound/ton, which provided 58 to 78 percent combustible recovery, depending on the frother need. Lower frother dosages gave significantly lower recoveries, while higher dosages provided no significant improvements in recovery. The effect of fuel oil dosage in presence of various frothers on clean coal ash and combustible recovery are shown in Figure 10. These results were obtained by maintaining a constant frother dosage of 1.5 pound/ton, and show that both recovery and clean coal ash were improved by the addition of fuel oil. Using MIBC, recovery improved from 67.0 to 82.4 percent, while the clean coal ash decreased from 13.2 to 9.5 percent ash by using 1 pound/ton fuel oil. Using M1150, 78.9 percent recovery was obtained at an ash content of 11.5 percent when using 1 pound/ton fuel oil. The best results were obtained with AF76, which provided 87.0 percent recovery at 9.7 percent ash when using 1 pound/ton fuel oil.

The effect of $\mathrm{pH}$ on flotation using the three frothers is shown in Figure 11. To conduct these tests, the frother dosage was maintained at 1.5 pound/ton, while the fuel oil dosage was kept at ${ }^{4}$ pound/ton. Optimum recovery was obtained near $\mathrm{pH} 6$ for MIBC (74 percent recovery) and AF76 (76.3 percent recovery). Recovery 
Table 2. Analysis of the Ziegler No. 26 Classifying Thickner Overflow

Characterization

\section{$1.55 \%$ Solids}

$\%$ Moisture

$\%$ Ash

Volatile Matter

Fixed Carbon

ETU

Chlorine

Sulfur (Total)

Pyritic Sulfur

Sulfate Sulfur

Organic Sulfur

1.55
28.00
26.1
44.4
10210
0.23
2.08
0.71
0.06
1.31

Ash

Wt $\% \quad \%$ Ash Distribution

4.17

12.02

13.82

$\underline{69.98}$

5.5

5.9

7.0

$-200+325$

$-500$

$\underline{36.8}$

3.5

$\underline{93.1}$

100.00

(26.67)

100.00 


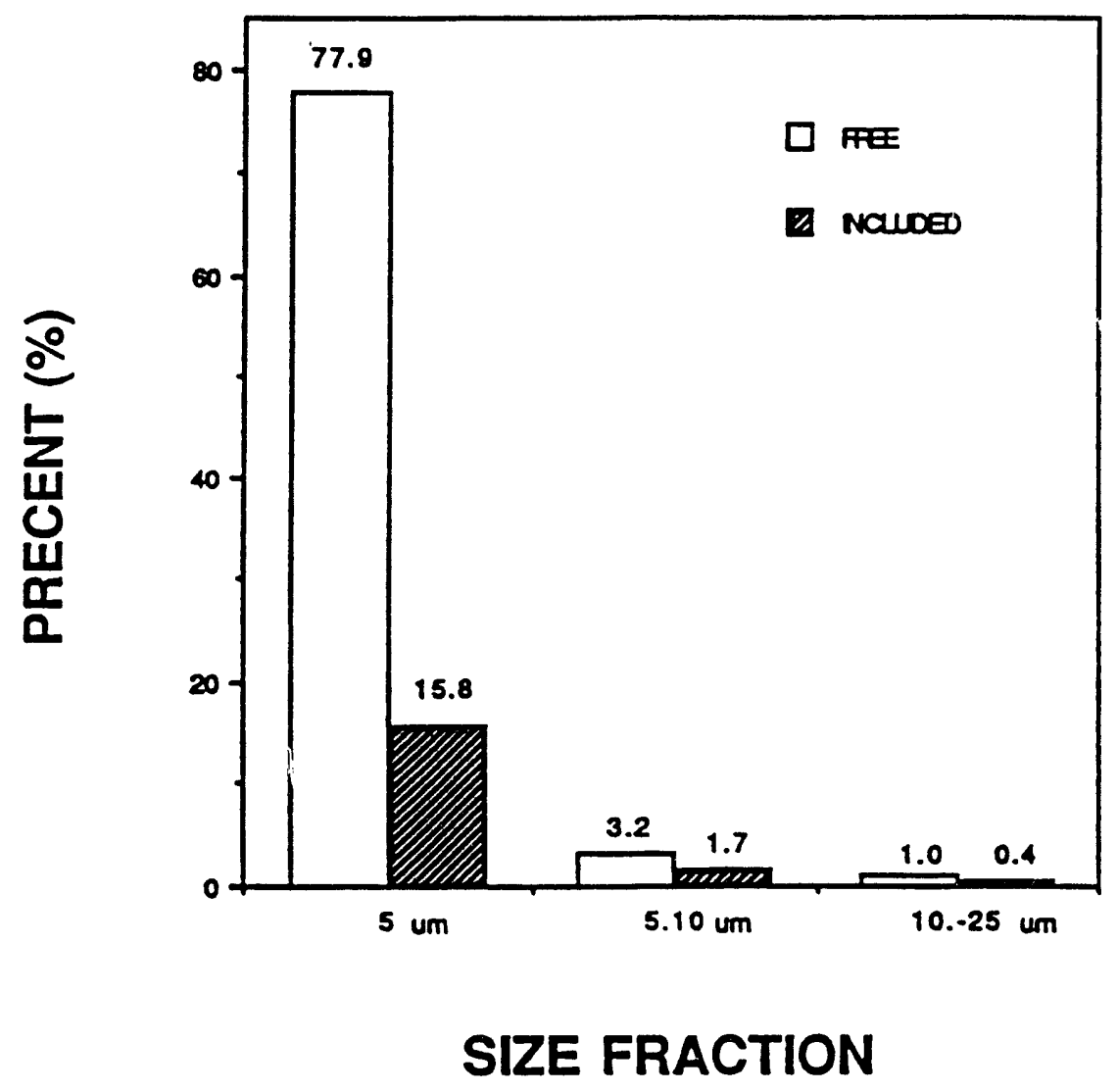

Figure 9. Size Distribution of Pyrite in the Ziegler No. 26 Classifying Thickner Overflow 


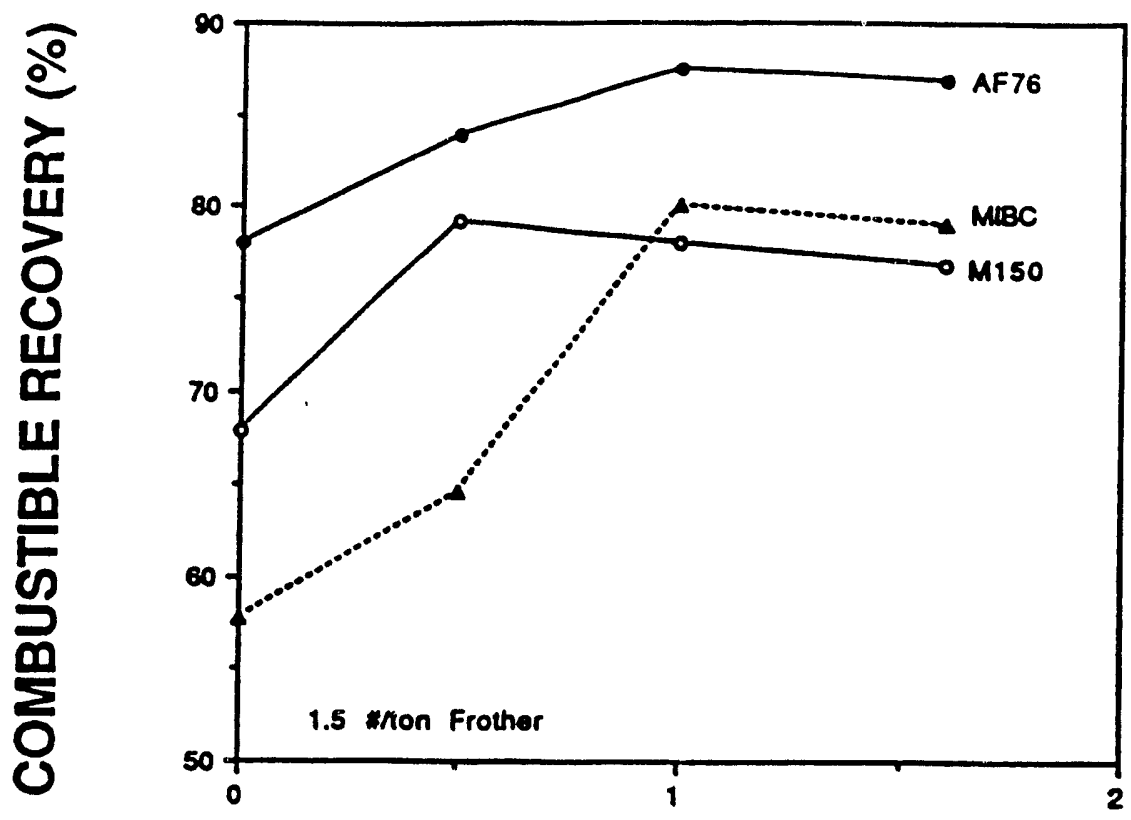

FUEL OIL DOSAGE (Ib/ton)

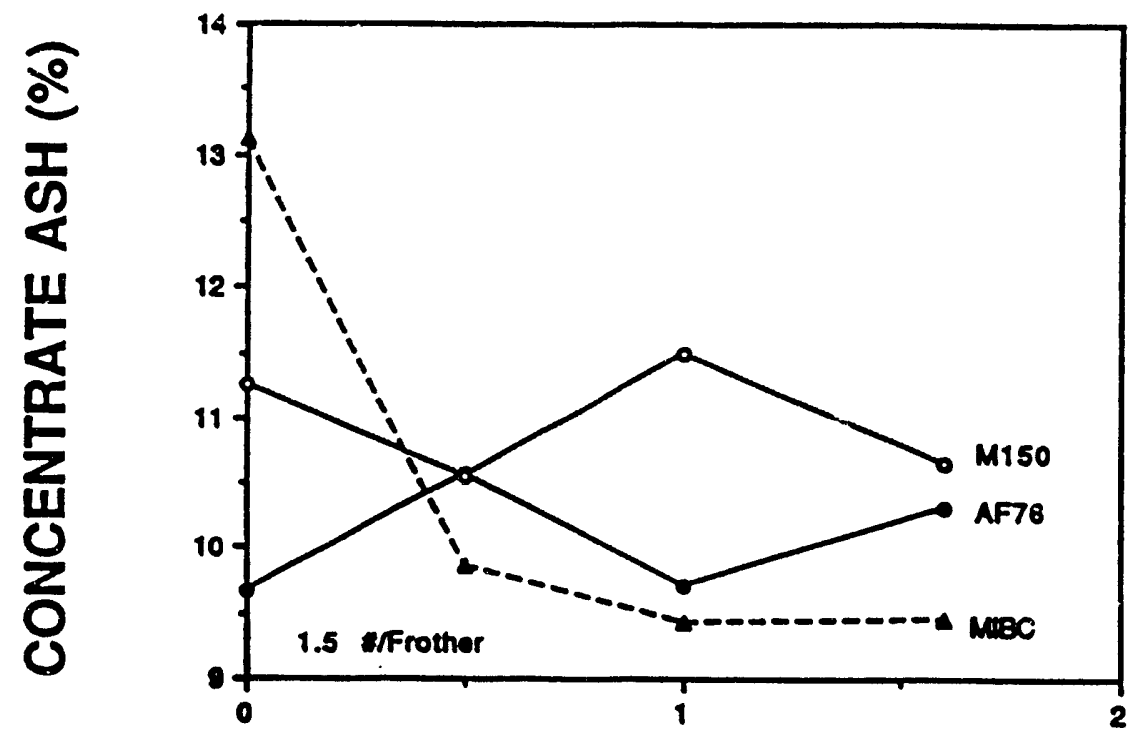

FUEL OIL DOSAGE (Ib/ton)

Figure 10. Effect of Fuel Oil Dosage on Combustible Recovery and Clean Coal Ash for Batch Flotation of the Ziegler Slurry 

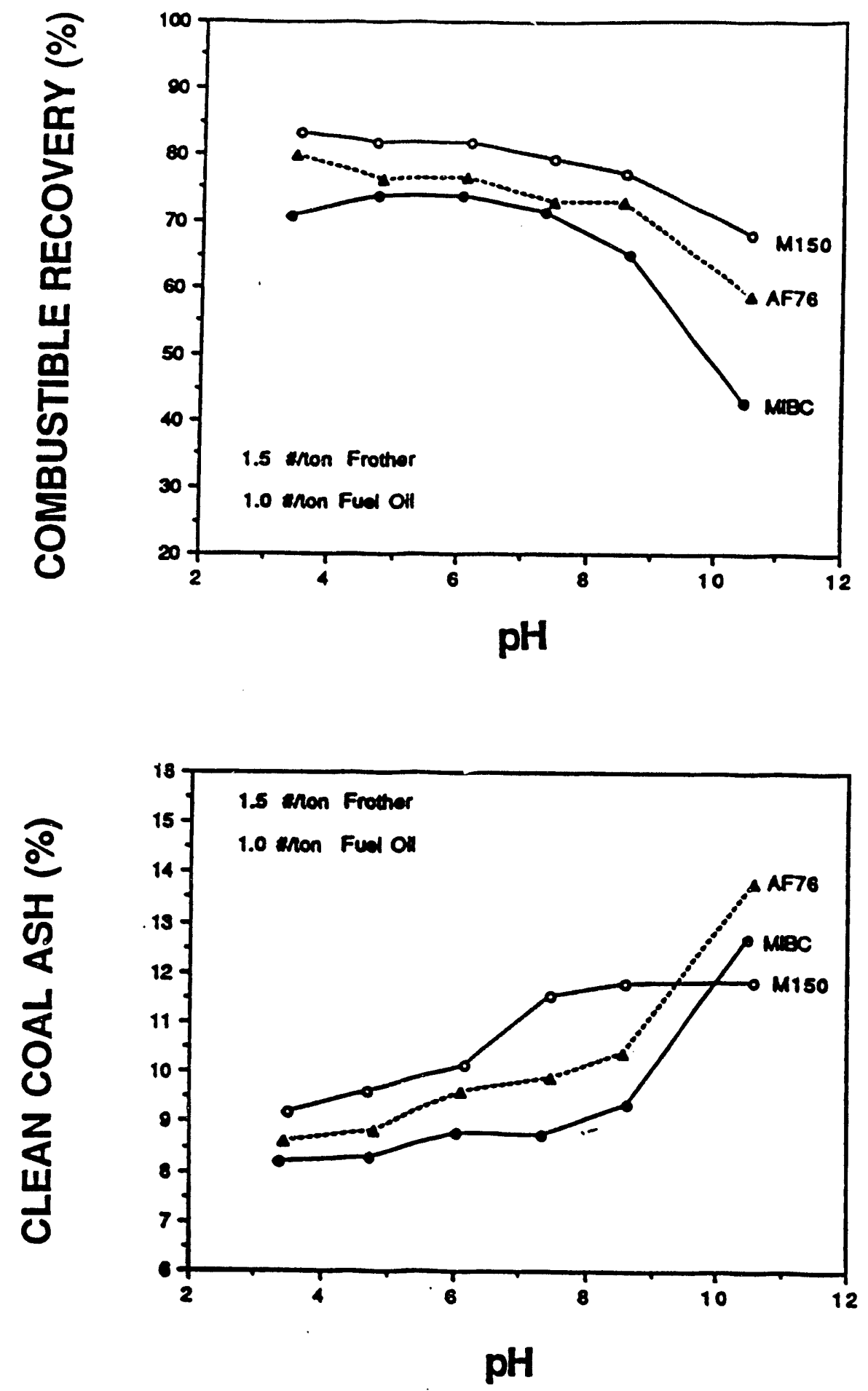

Figure 11. Effect of pH on Combustible Recovery and Clean Coal Ash for Batch Flotation of the Ziegler Slurry 
diminished for both frothers when the $\mathrm{pH}$ was either lower than 5 or higher than 8 . Recovery with M150 remained unchanged (72-79 percent recovery) throughout the pH range tested.

As the $\mathrm{pH}$ was increased from 3.4 to 10.5 , the clean coal ash obtained using MIBC increased from 8.2 to 12.7 percent ash, while for AF76, the ash increased from 8.6 to 13.8 percent. With M150, the clean coal ash increased from 9.2 to 11.9 percent over the same $\mathrm{pH}$ range. These results suggest that acidic $\mathrm{pH}$ provides lower ash content in the froth. As the pH is increased, the clean coal ash also increases, possibly due to increased dispersion of ash particles.

Flotation tests were conducted using two ash depressants while maintaining reagent dosages at 1.5 pound/ton MIBC and 1.0 pound/ton fuel oil. No significant improvements in clean coal ash or ash rejection were apparent at dosages as high as 5.0 pound/ton. Results obtained using pyrite depressant $\mathrm{WH}-1$ were similar to those obtained with the Galatia slurry. Pyrite rejection improved from 44.2 to 64.5 percent using 5 pound/ton WH-1; however, combustible recovery decreased from 83.6 to 53.4 percent, indicating that $\mathrm{WH}-1$ exhibited depressant activity on the coal as well as the pyrite.

\section{Column Flotation Tests}

Results obtained in column flotation tests with the Ziegler slurry are presented in Appendix $B$, while the optimum results obtained with each frother and bubblegenerating device are summarized in Figures 12-14. When MIBC was used as frother, the sparger provided 91.7 percent combustible recovery, 5.02 percent clean coal ash and 61.9 percent pyrite rejection (Figure 12). Similar results were obtained with the gas saver and the foam jet. Maximum pyrite rejection (66.4 percent) using MIBC was obtained with the foam jet, which gave 89.5 percent combustible recovery and 4.24 percent clean coal ash.

When AF76 was used as frother (Figure 13), a combustible recovery of 94.5 percent with the sparger, 91.2 percent with the foam jet and 86.3 percent with the gas saver was obtained. The best pyrite rejection obtained with this frother was 65.6 percent with the foam jet, while the clean coal ash content was 4.35 percent ash.

Using M150 frcther and sparger combination provided combustible recovery of 89.6 percent with 6.19 percent clean coal ash and 60.9 percent pyrite rejection (Figure 14). Results obtained with the gas saver were quite similar; however, the clean coal ash content was only 3.89 percent ash. The best results were obtained with an M150 and foam jet combination, which provided 91.5 percent combustible recovery, 4.13 percent ash in the clean coal and 66.4 percent pyrite rejection.

When WH-1 was used as a depressant, no significant improvement in pyrite rejection occurred at dosages as high as 5 pound/ton. Combustible recovery did decrease to 87.3 percent at this dosage. 


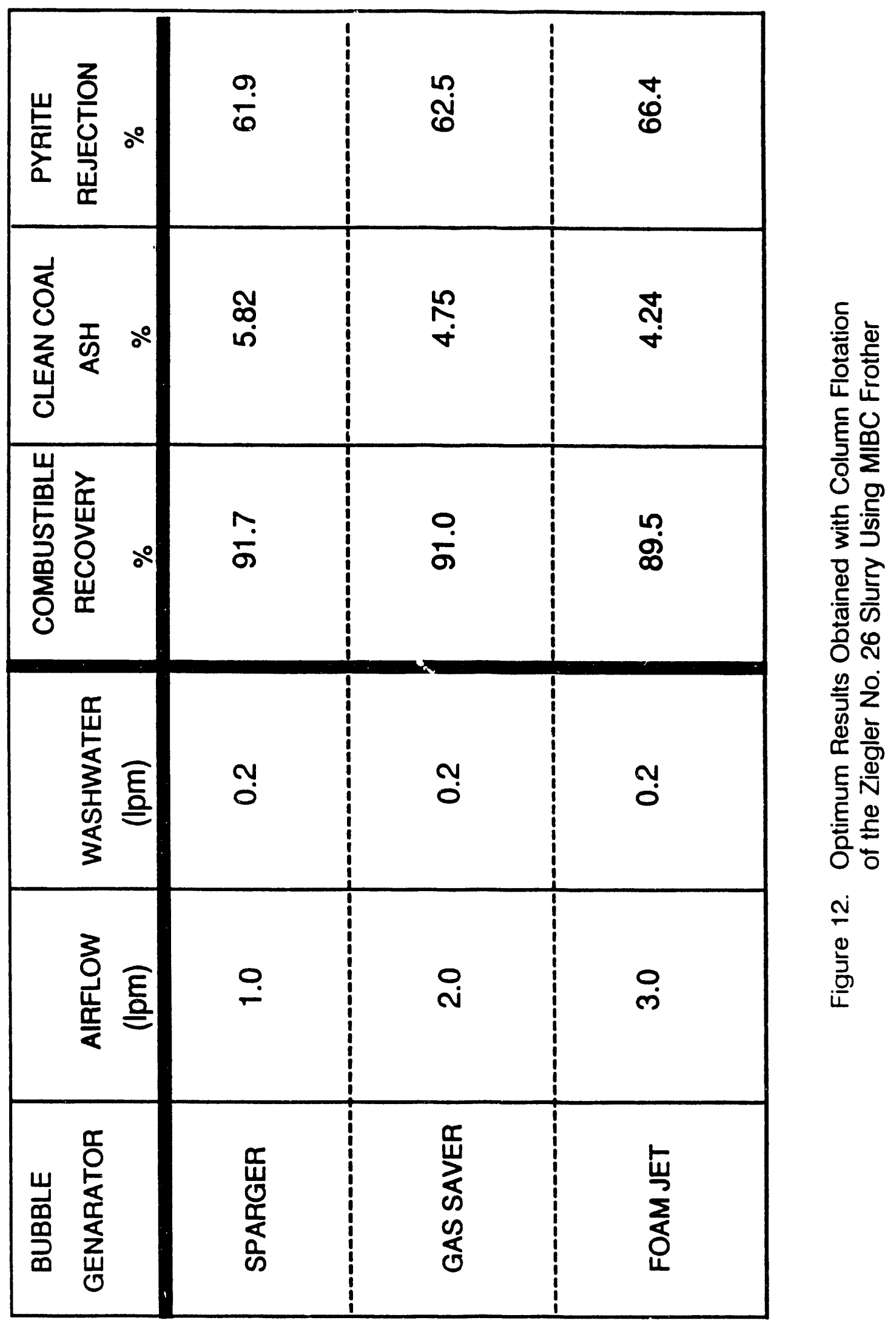




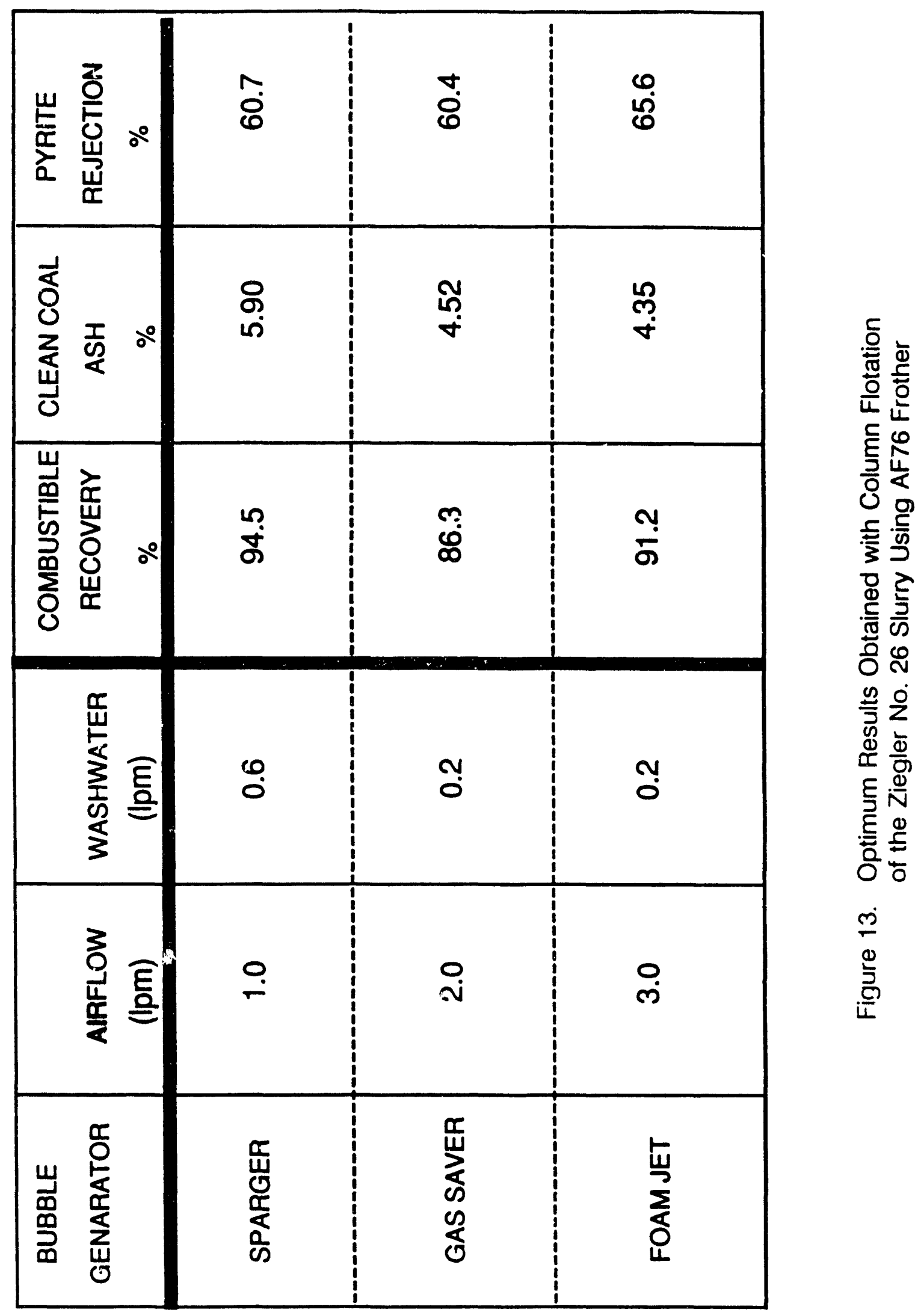




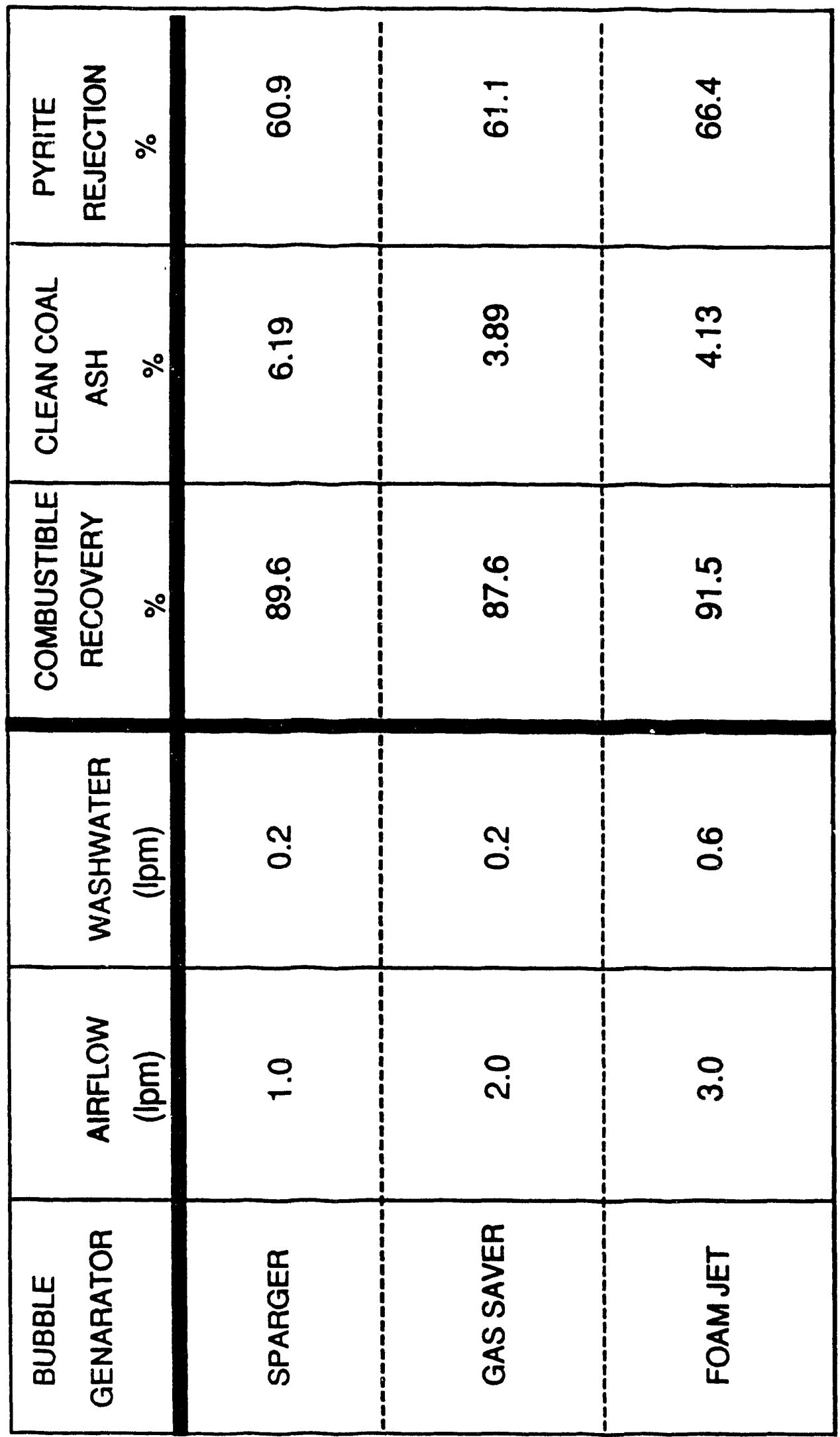

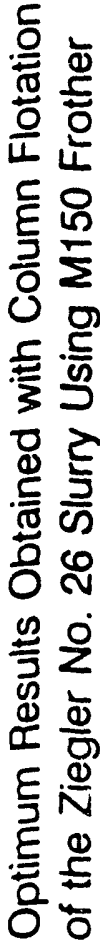

$\frac{\dot{\Xi}}{\frac{0}{3}}$ 
In summary, optimum reagent addition for the Ziegler No. 26 slurry was 1.5 pound/ton frother and 1.0 pound/ton fuel oil. Results obtained with each of the three frothers and bubble generators were similar; however, pyrite rejection was consistently higher for each frother when the foam jet was used for bubble generation.

\section{Pilot-Scale Column Flotation Testing}

Continuous pilot-scale column flotation testing was conducted on the Galatia slurry utilizing a 6-inch diameter column flotation cell. All testing was conducted at CAER, and reagent dosages were maintained at 1.0 pound/ton MIBC and 1.5 pound/ton fuel oil. The slurry used for pilot-scale testing contained 3.5 percent solids, which was the same as the slurry used for laboratory testing. However, the pilot-scale slurry contained 59.3 prcent ash and 1.66 percent pyrite sulfur versus 41.0 percent ash and 1.16 percent pyrite sulfur for the laboratory scale slurry.

Results of pilot-scale testing showed that despite using such a high ash content feed (59.3 percent ash), combustible recoveries of 75-85 percent were consistently obtained. The clean coal ash content was 5.5-6.3 percent ash (96-97 percent ash rejection) when the sparger was used for bubble generation and 3.5-4.0 percent ash (98-99 percent ash rejection) when the foam jet was used.

The pyritic sulfur content of the clean coal obtained using the sparger was 1.36-1.06 percent (73.5-79.5 percent pyrite rejection); while for the foam jet, the clean coal contained only 1.04-0.75 percent pyrite sulfur (75.1-85.7 percent pyrite rejection).

These results show the pilot-scale column flotation can provided results $s$ inilar to the laboratory column; and a low ash, low pyritic clean coal was obtained at high combustibie recovery.

\section{CONCLUSIONS AND RECOMMENDATIONS}

Based on the experimental data presented in this report, it can be concluded that for the Kerr-McGee flotation feed:

- Column fotation of the Kerr-McGee Galatia flotation feed provided combustible recovery ranging from 88 to 92 percent, whereas the conventional batch flotation provided about 80 percent combustible recovery when MIBC; as well as AF76, were used as frothers. M150 gave similar combustible ( 90 percent) recovery in both batch and column flotation tests.

- Column flotation provided lower ash clean coal than batch flotation when all three frothers were used. With MIBC and AF76 frothers, clean coal ash in the batch flotation product ranged from 12 to 14 percent; whereas 
for column flotation it ranged from 4 to 8 percent. For M150 frother, the clean coal ash obtained in batch flotation was 18 percent, while column flotation provided 4 to 6 percent ash clean coal.

- Column flotation provided pyrite rejection of 50-80 percent, depending on the column-operating conditions and the type of frother. The best results were obtained with the foam jet and M150 frother, where 77 percent pyrite rejection was achieved while maintaining 90 percent recovery of combustibles.

- M150 was an effective frother for all three bubble-generating systems tested, providing high ( $>90$ percent combustible recovery and low ash clean coal (4-6 percent ash).

In addition, it can be concluded that for the Ziegler No. 26 slurry,

- Column flotation provided 85-95 percent combustible recovery, while conventional batch flotation provided 78-80 percent recovery when MIBC or M150 were used as frothers. AF76 provided similar recovery in both batch and column flotation testing.

- Column flotation provided 4 to 7 percent clean coal ash when any of the three frothers were used, compared to clean coal ash of 9.5-11 percent obtained in batch flotation.

- $\quad$ Column flotation achieved 50-67 percent pyrite rejection, depending on the conditions employed. The best results were obtained using MIBC and the sparger where 60 percent pyrite rejection was obtained while maintaining 93 percent combustible

\section{RECOMMENDATIONS}

Based on the above-mentioned conclusions, it is recommended that a demonstration column flotation unit capable of processing up to 100 gallons per minute of slurry should be installed and tested at one of the lllinois preparation plants, preferably Ziegler No. 26. This demonstration project will provide additional data which will be helpful in the designing of larger commercial scale columns. The columns have shown the potential to provide a low-ash, log-pyritic sulfur for llinois high sulfur coal fine waste refuse streams. The demonstration unit will provide more convincing proof to the llinois coal industry and will encourage utilization of the advanced flotation process. 


\section{REFERENCES}

1. Aplan, F.F., 1976, "Coal Flotation," chapter 45. A.M. Gaudin Memorial Symposium, M.C. Fuerstenau (Ed.) AIME, pp. 1235-1264.

2. Fuerstenau, D.W., M.C. Williams and R. Herrera-Urbina, 1987, "Characterization of Coal Surfaces," Final Report DOE Grant No. DE-FG22-84PC70776.

3. Morsi, B., 1991, "Coal Surface Control for Advanced Physical Coal Cleaning Technologies," Seventh Annual Coal Preparation, Utilization and Environmental Control Contractors Conference, Pittsburgh, Pa.

4. Aplan, F.F., 1977, "Use of Flotation Process for Desulfurization of Coal," Coal Desulfurization, T.D. Wheelock (Ed.), ACS Symposium Series 64.

5. Perry, R.W. and F.F. Aplan, 1985 "Polysachharides and Xanthated Polysaccharides as Pyrite Depressant during Coal Flotation, Processing, arid Utilization of High Sulfur Coals," Y. Attia (Ed.), Elsevier, pp. 215-238.

6. Kawatra, S.K., and T.C. Eisele, 1988, "Studies Relating to Removal of Pyritic Sulfur from Coal by Column Flotation," Chapter 22, Column Flotation '88, K.V.S. Sastry (Ed.) AIME.

7. Yoon, R.H. et al, 1990, "Recent Advances in Fine Coal Flotation", "Advances in Coal and Mineral Processing Using Flotation," S. Chander and R. R. Klimpel (Ed.), AIME, pp. 211-218.

8. Yang, D.C., 1990, "Packed Bubble Column Flotation of Fine Coal," Coal Preparation, Vol. 8, pp. 19-48.

9. Christophersen, J.A., and A.J. Jonaitis, 1990, "Diester Flotaire Column Flotation Cell - Plant Experience", "Advances in Coal and Mineral Processing Using Flotation, S. Chander and R.R. Klimpel (Eds.), AlME, pp. 113-119.

10. Parekh, B.K., A.E. Bland, J.G. Groppo and J. Yingling, 1990, "A Parametric Study of Column Flotation for Fine Coal Cleaning," Coal Preparation, Vol. 8, pp. 49-60.

11. Parekh, B.K., A.E. Bland and W.F. Stotts, 1988, "Advanced Froth Flotation Cell Design: 'Ken-Flote' Column Performance on Ultrafine Coal," submitted to U.S. DOE, Pittsburgh, $\mathrm{Pa}$. 
APPENDIX A 


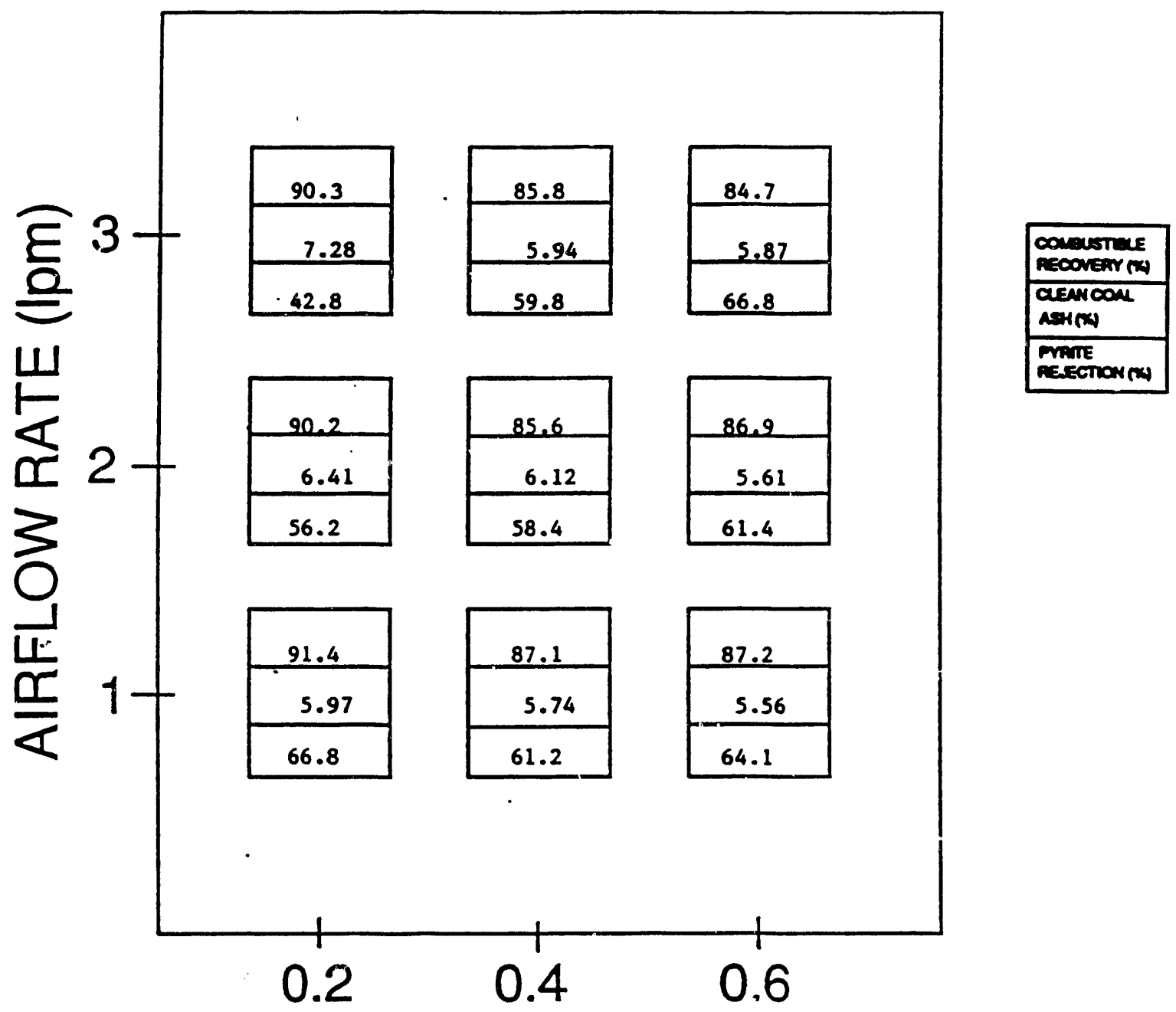

WASHWATER (lpm)

Figure A1. Effect of Airflow and Washwater Rates on Combustible Recovery, Clean Coal Ash and Pyrite Rejection for the Galatia Slurry Using the Static Sparger and MIBC Frother 


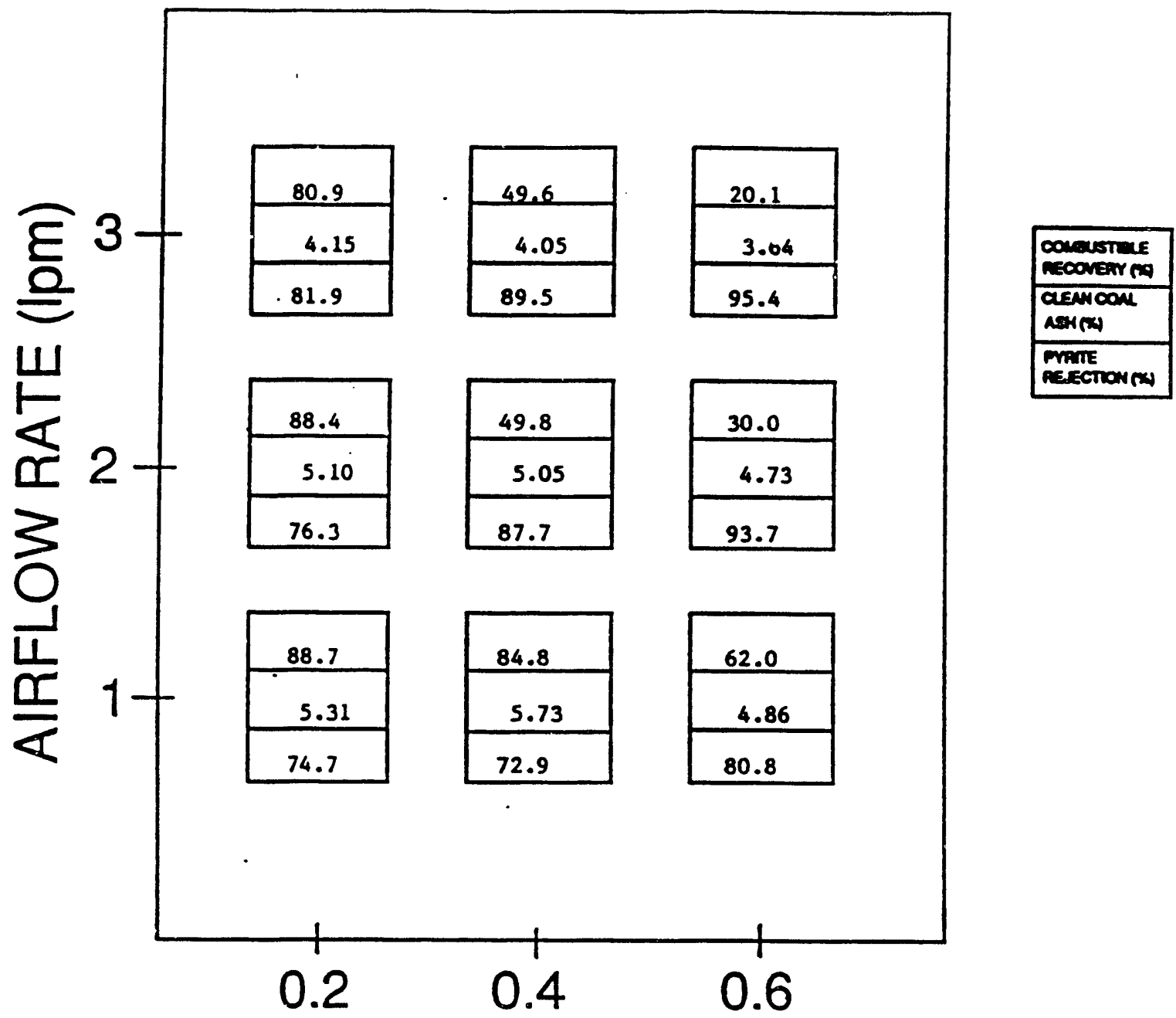

WASHWATER (lpm)

F1gure A2. Effect of Airflow and Washwater Rates on Combustible Recovery, Clean Coal Ash and Pyritic Rejection for the Galatia Slurry Using the Foam Jet Sparger and MIBC Frother 


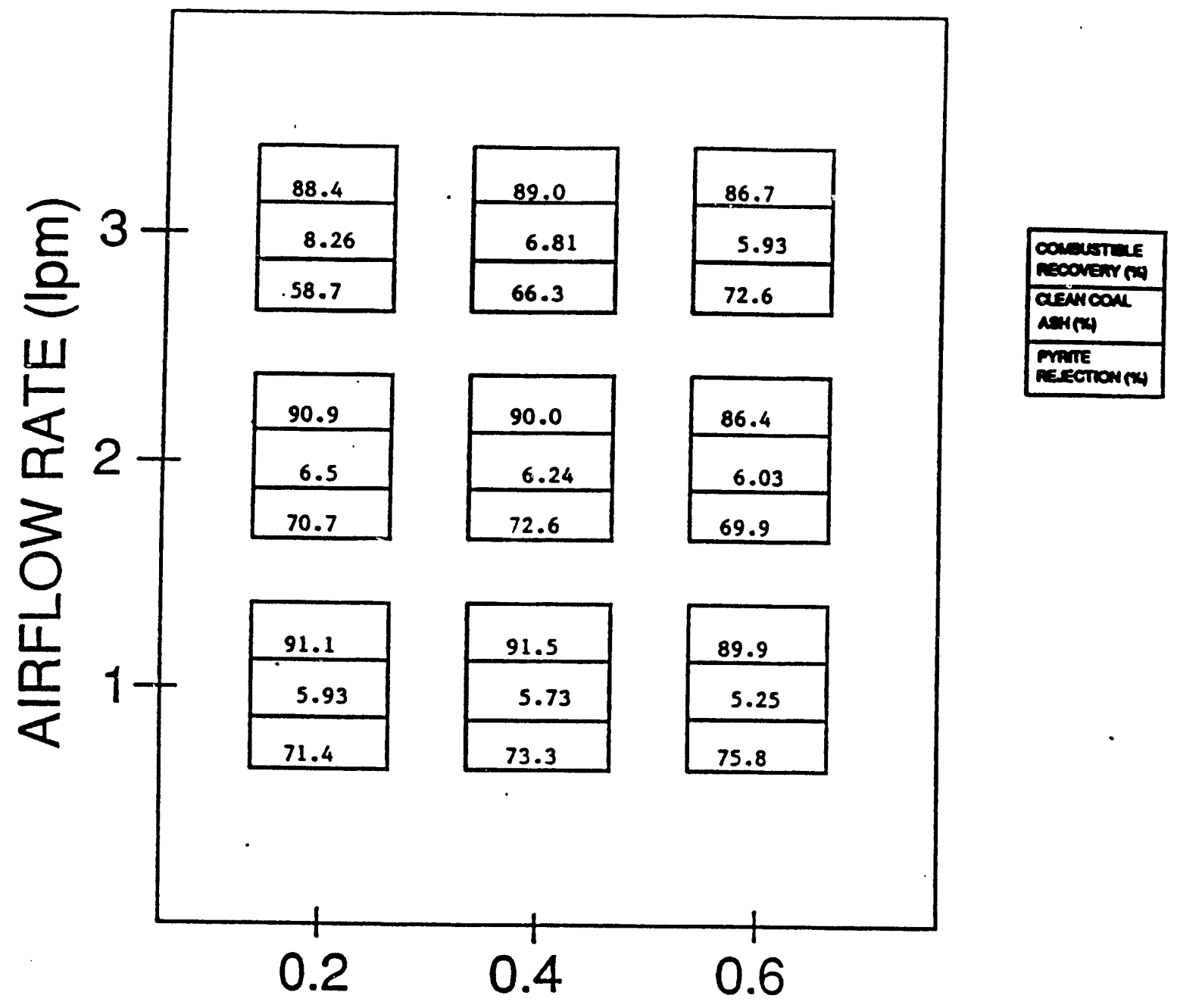

WASHWATER (Ipm)

Figure A3. Effect of Airfiow and Washwater Rates on Combustible Recovery, Clean Coal Ash and Pyritic Rejection for the Galatia Slurry Using the Static Sparger and AF76 Frother 


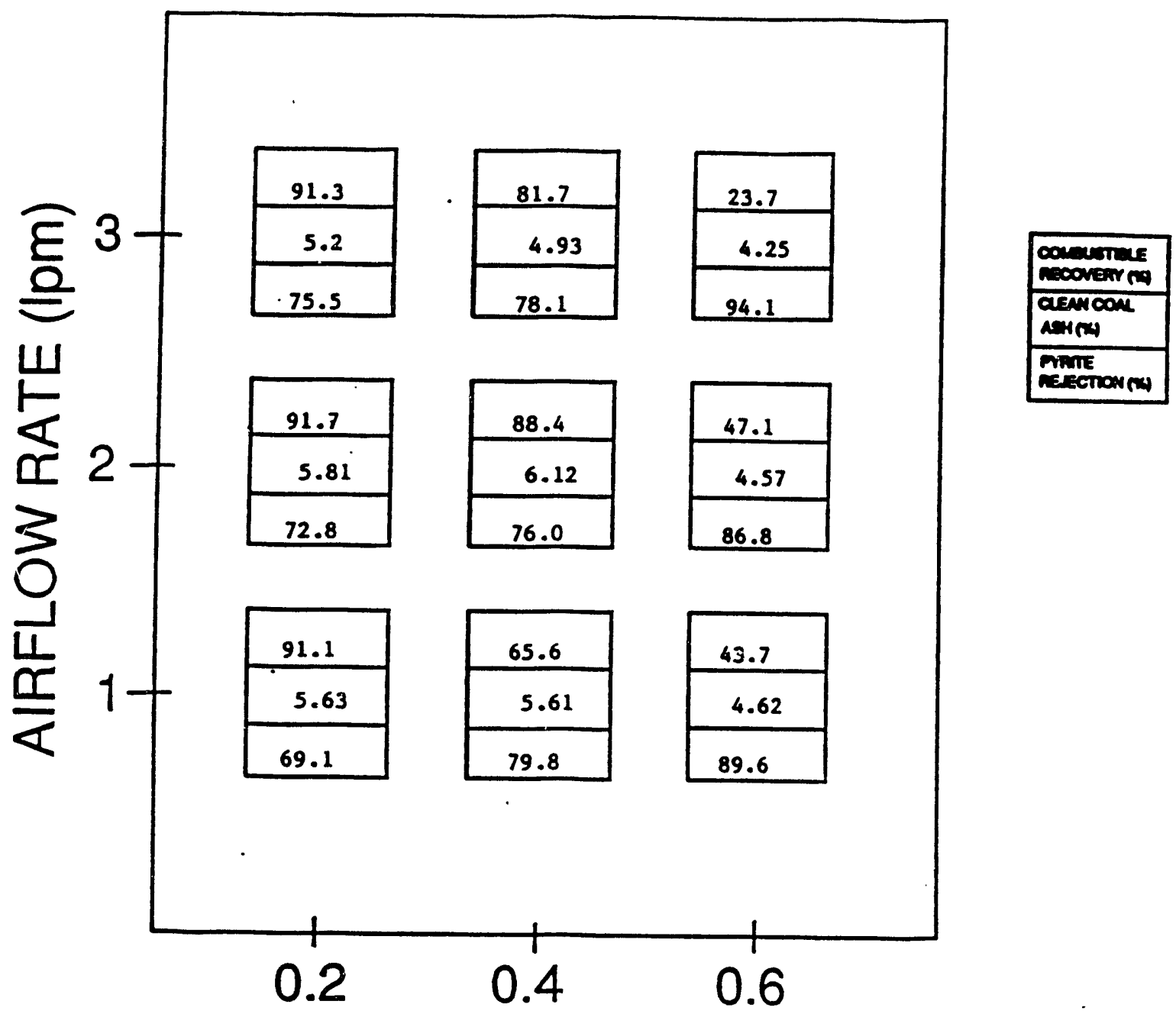

WASHWATER (lpm)

F1gure A4. Effect of Airflow and Washwater Rates on Combustible Recovery, Clean Coal Ash and Pyritic Rejection for the Galatia Slurry Using the Foam Jet and AF76 Frother 


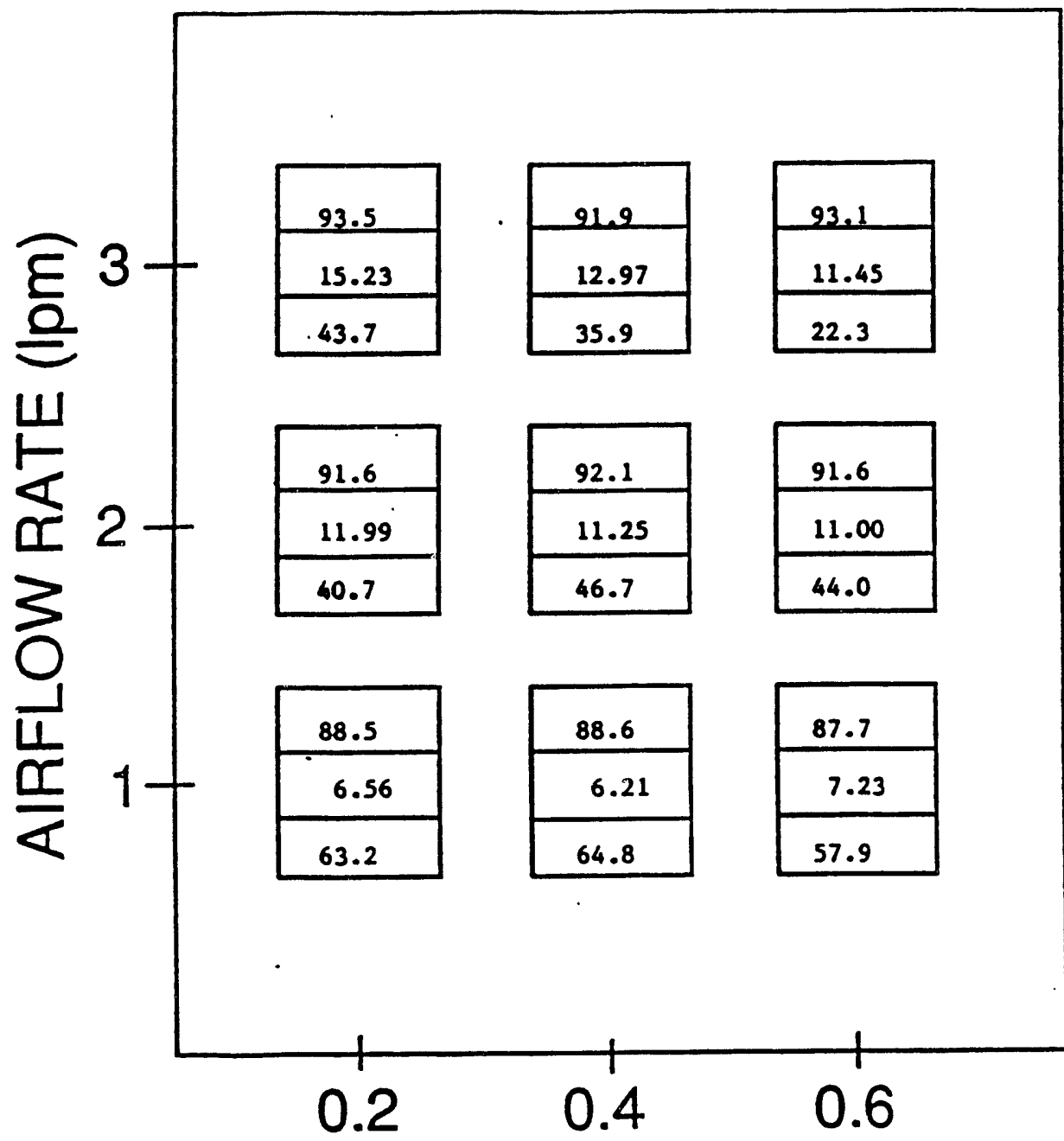

Figure A5. Effect of Airfiow Rates on Combustible Recovery, Clean Coal Ash and Pyrite Rejection for the Galatia Slurry Using the Static Sparger and M150 Frother 


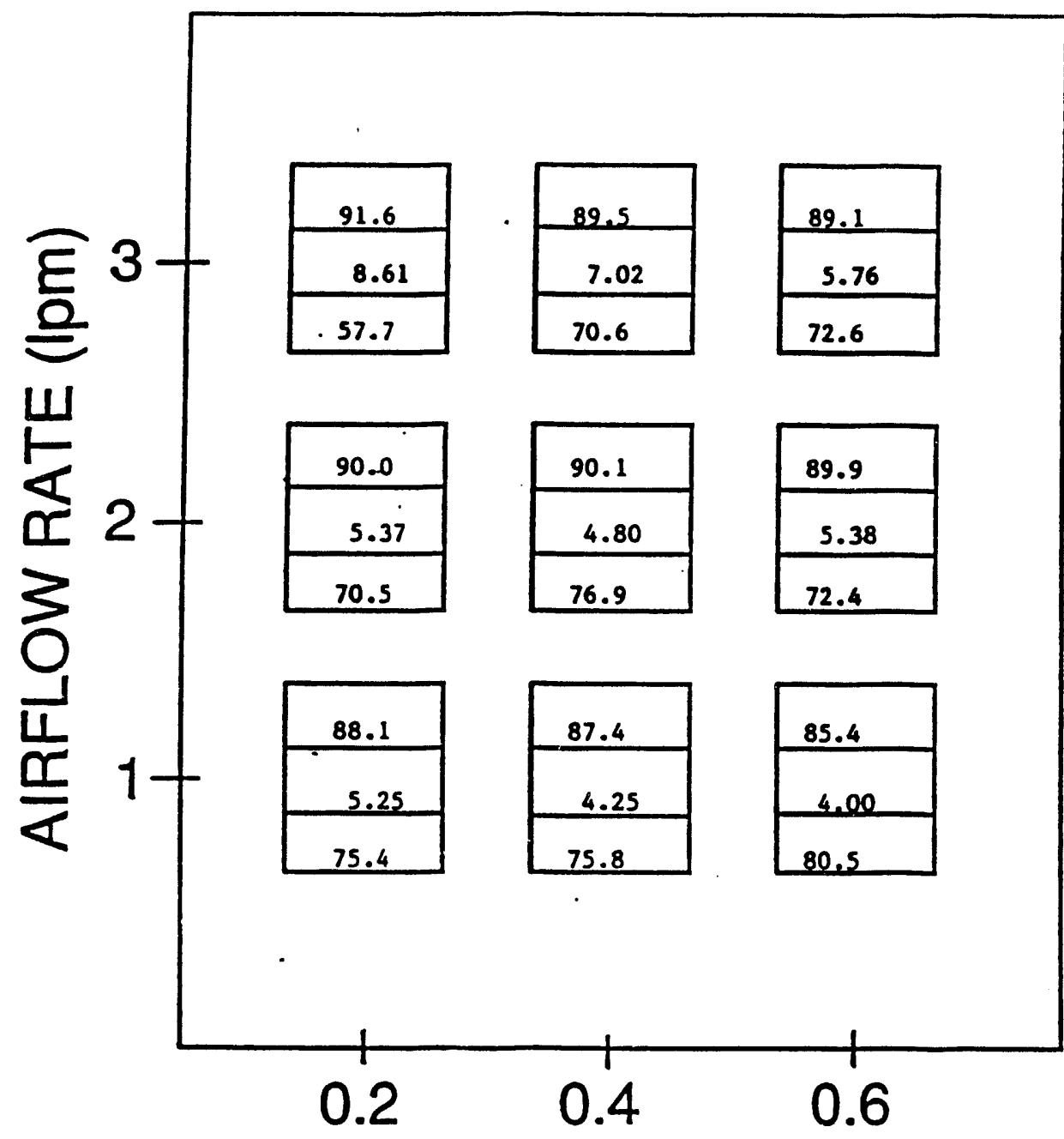

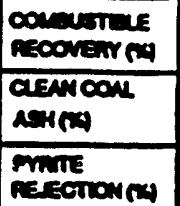

WASHWATER (lpm)

Figure A6. Effect of Airflow and Washwater Rates on Combustible Recovery, Clean Coal Ash and Pyrite Rejection for the Galatia Slurry Using the Gas Saver Sparger and M150 Frother 


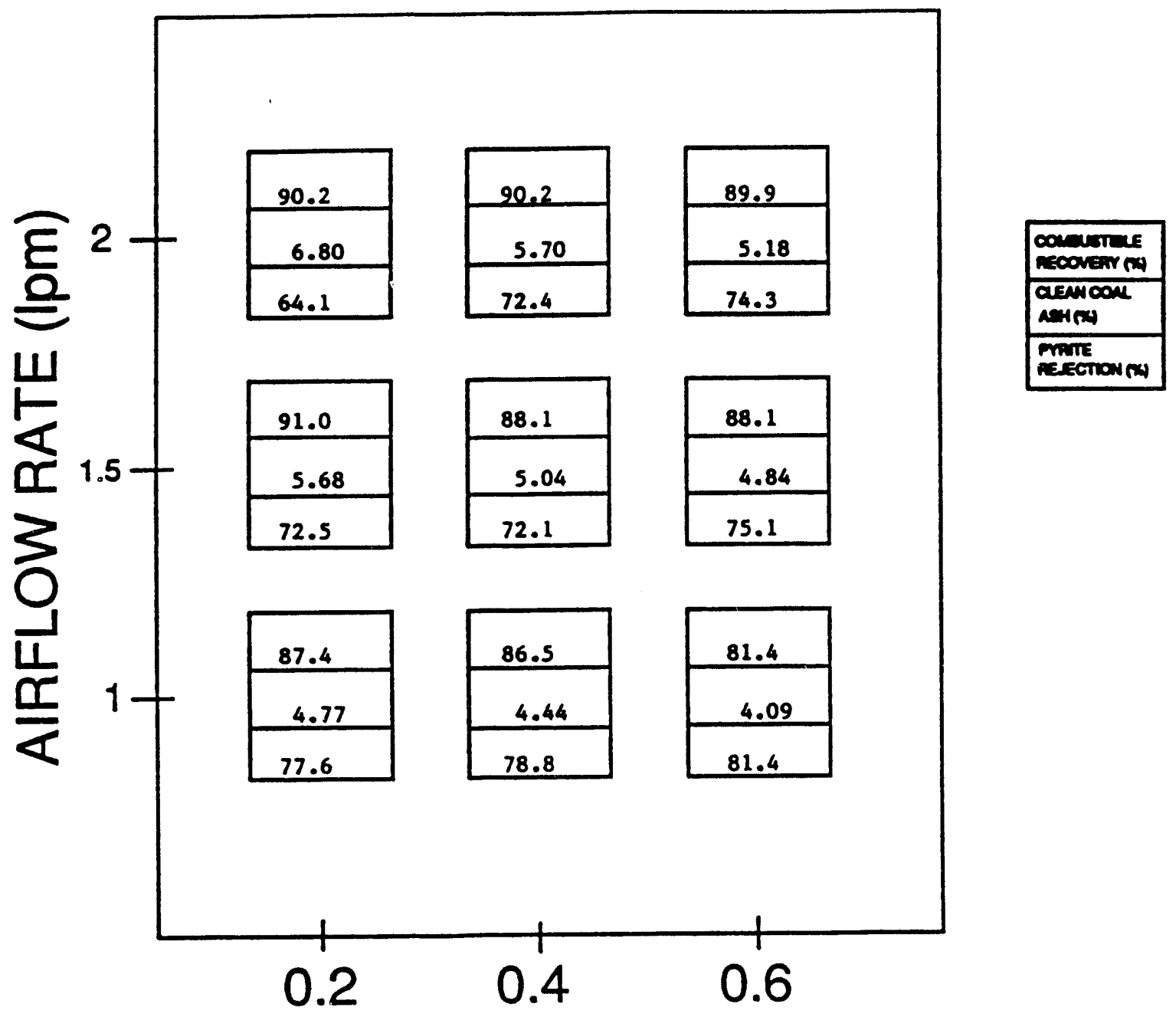

WASHWATER (lpm)

Figure A7. Effect of Airflow and Washwater Rates on Combustible Recovery, Clean Coal Ash and Pyrite Rejection for the Galatia Slurry Using the Foam Jet Sparger and M150 Frother 
APPENDIX B 


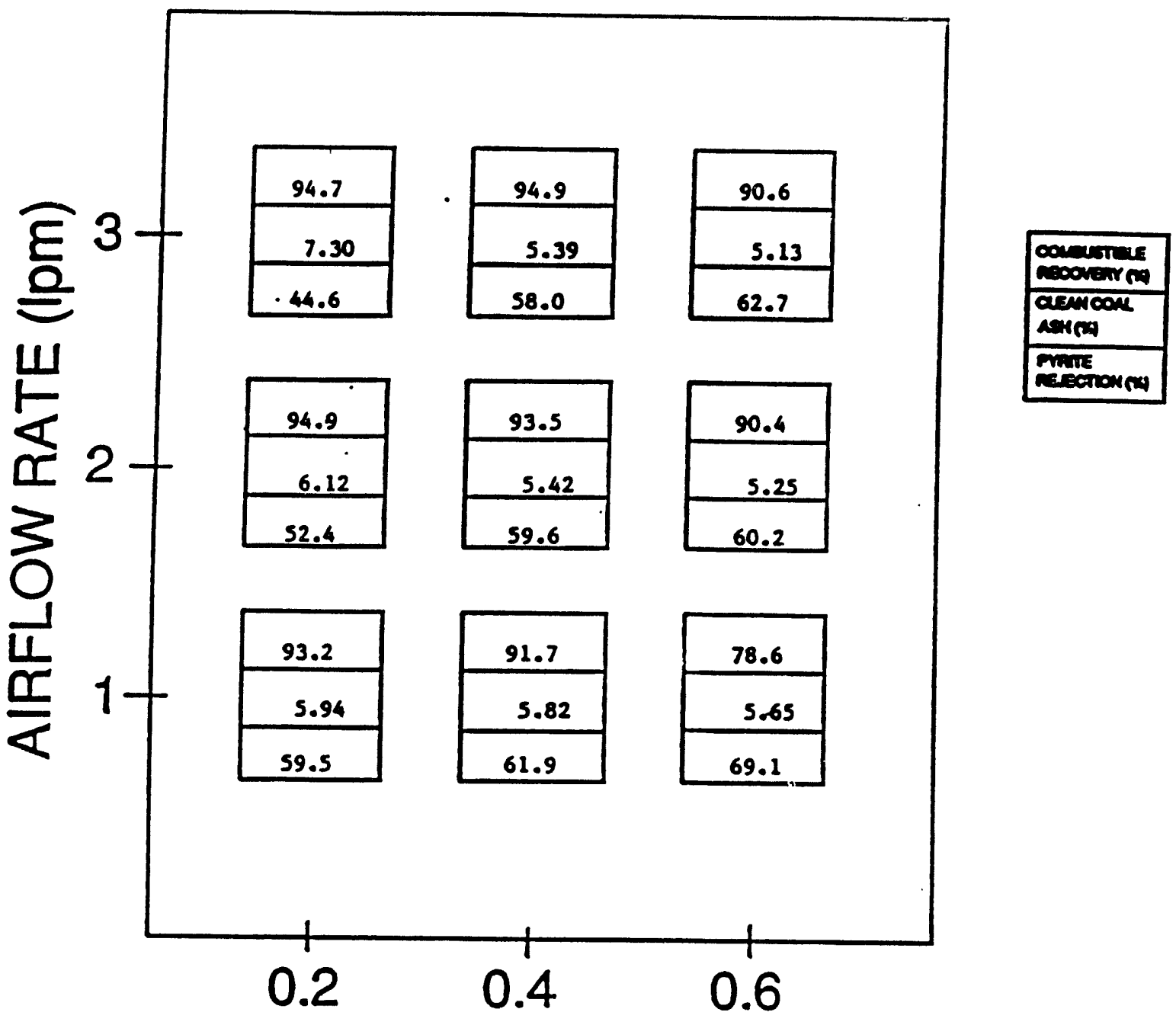

WASHWATER (Ipm)

Figure B1. Effect of Airflow and Washwater Rates on Combustible Recovery, Clean Coal Ash and Pyrite Rejection for the Ziegler Slurry Using the Static Sparger and MIBC Frother 

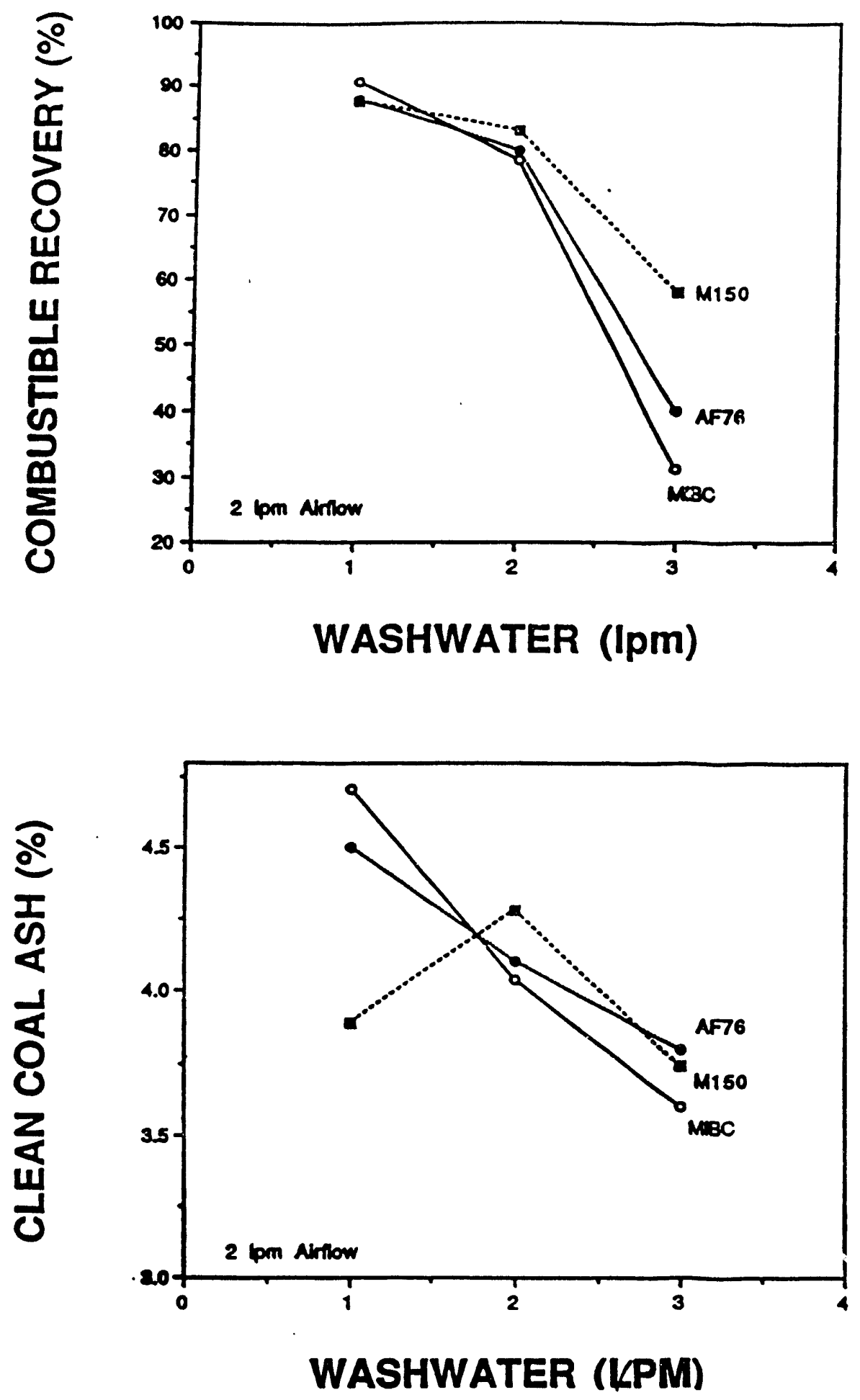

Figure B2. Effect of Washwater Addition Rates on Combustible Recovery for the Ziegler Slurry Using the Gas Saver Sparger and 3 Frothers 


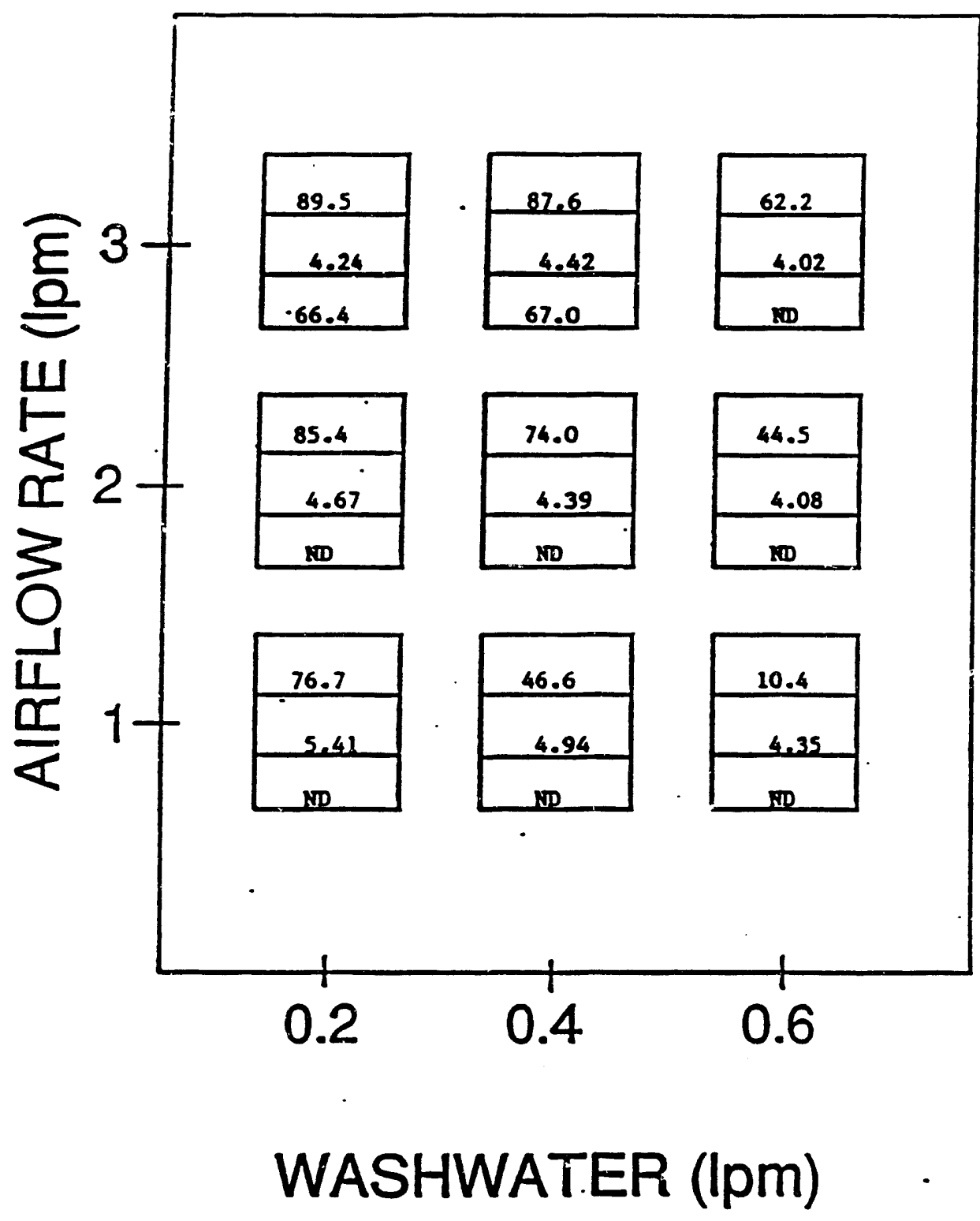

Figure B3. Effect of Airflow and Washwater Rates on Combustible Recovery, Clean Coal Ash and Pyrite Rejection for the Ziegler Slurry Using the Foam Jet Sparger and MIBC Frother

$\mathrm{ND}=$ Not determined 


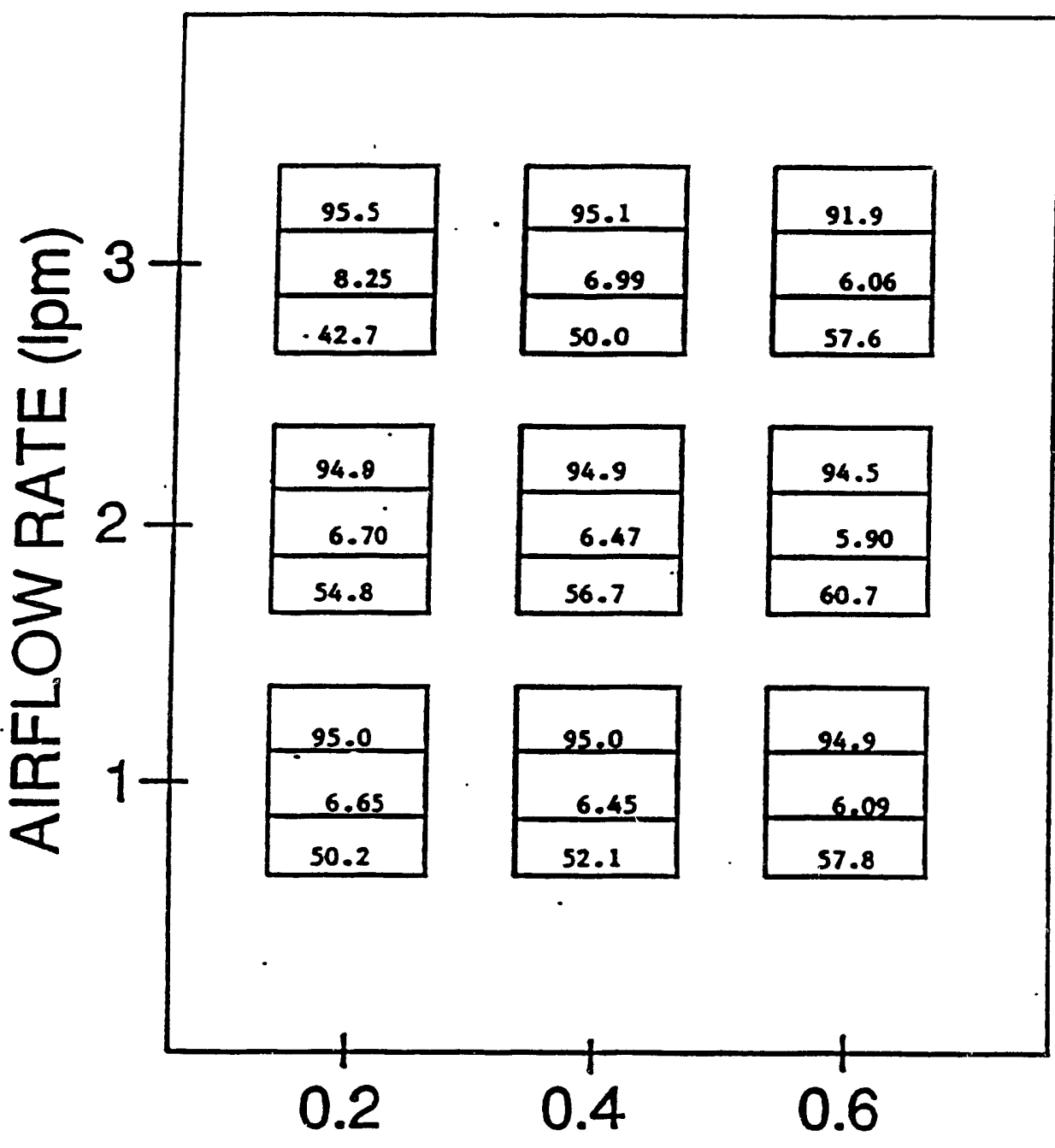

\begin{tabular}{|c|}
\hline cominge \\
\hline 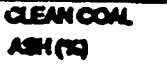 \\
\hline Minue \\
\hline
\end{tabular}

WASHWATER (lpm)

F1gure B4. Effect of Airflow and Washwater Rates on Combustible Recovery, Clean Coal Ash and Pyrite Rejection for the Ziegler Slurry Using the Static Sparger and AF76 Frother 


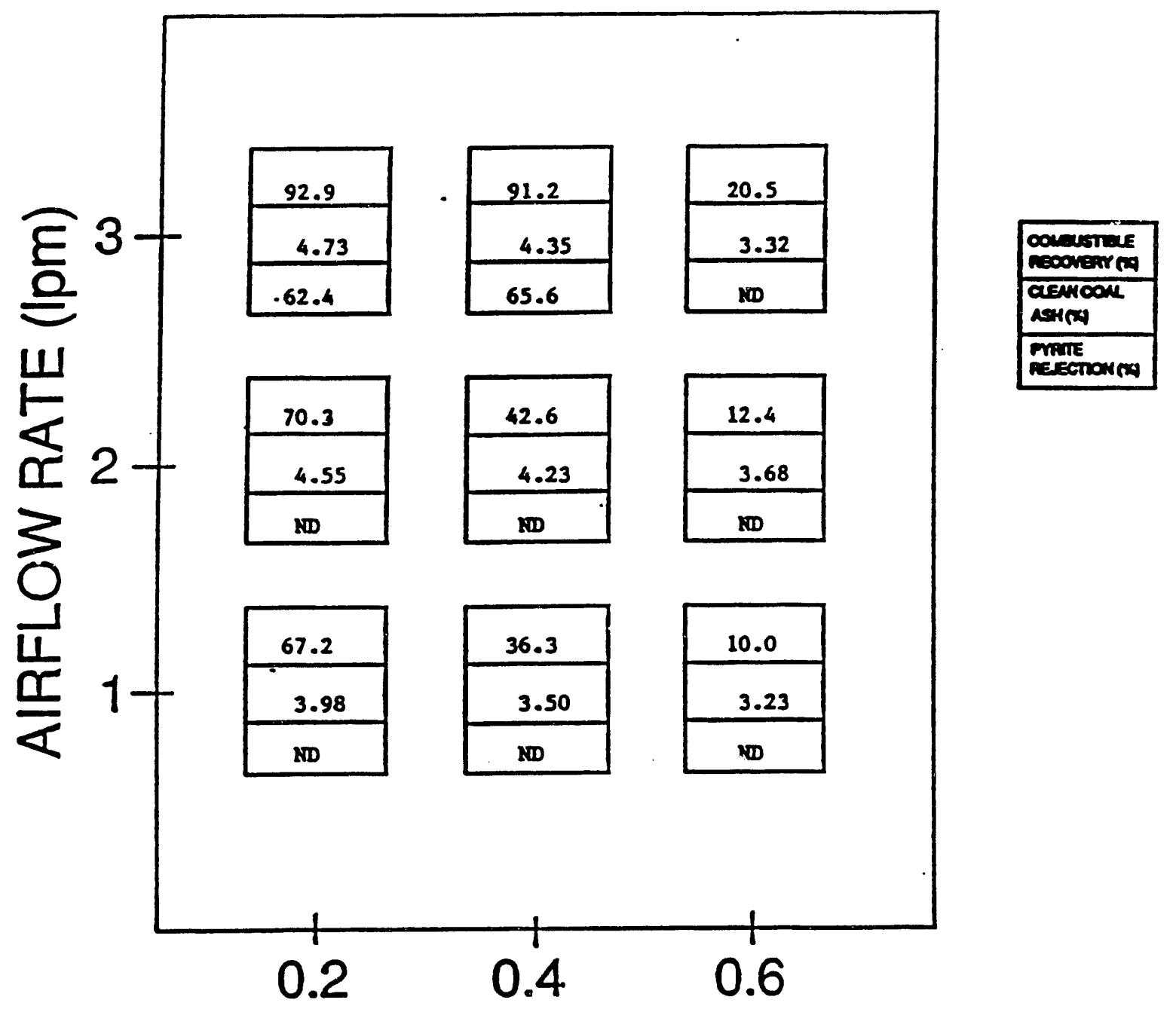

\section{WASHWATER (Ipm)}

Figure B5. Effect of Airflow and Washwater Rates on Combustible Recovery, Clean Coal Ash and Pyrite Rejection for the Ziegler Slurry Using the Foam Jet Sparger and AF76 Frother

$\mathrm{ND}=$ Not determined 


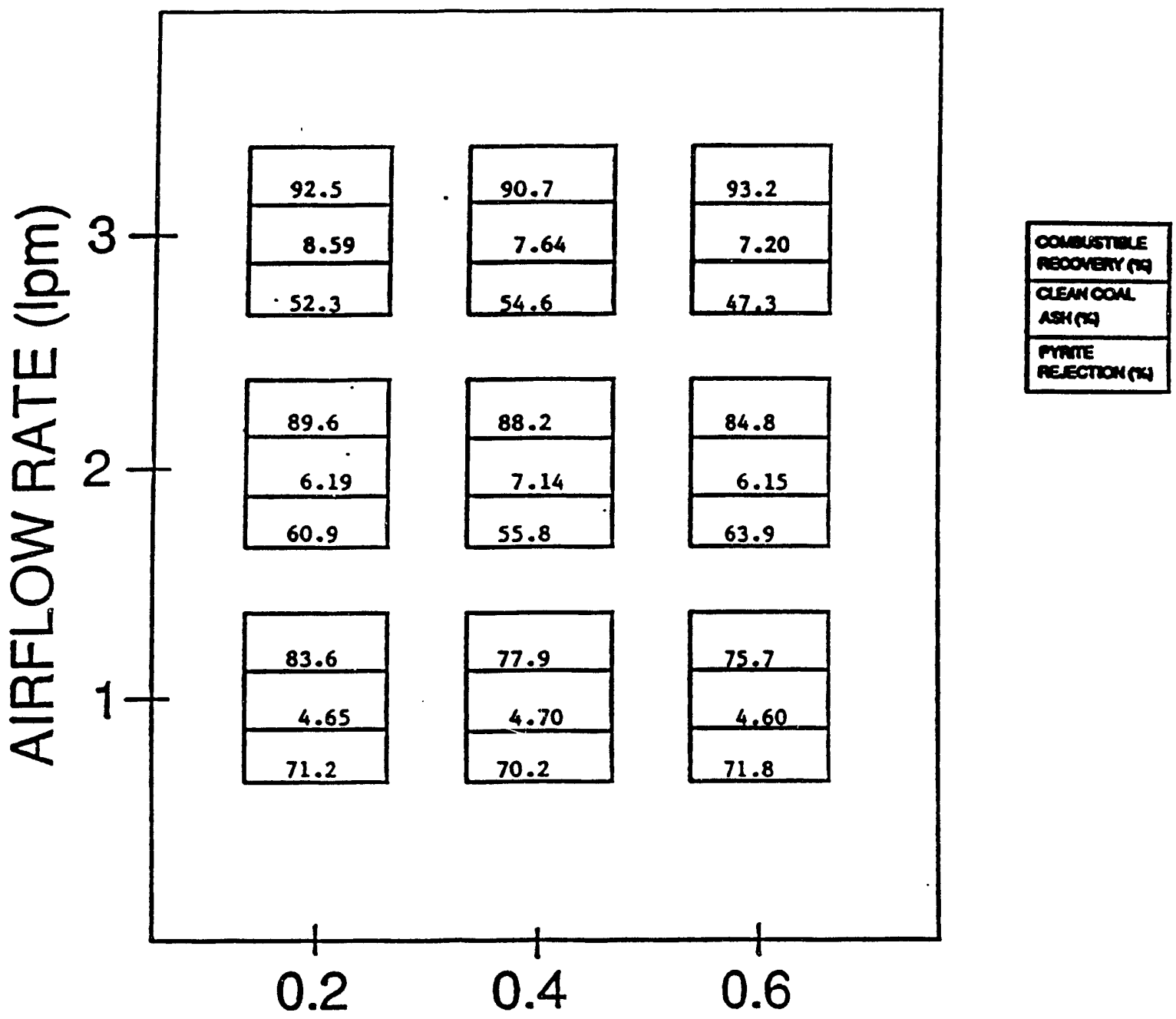

WASHWATER (lpm)

Figure B6. Effect of Airflow and Washwater Rates on Combustible Recovery, Clean Coal Ash and Pyrite Rejection for the Ziegler Slurry Using the Static Sparger and MIBC Frother 


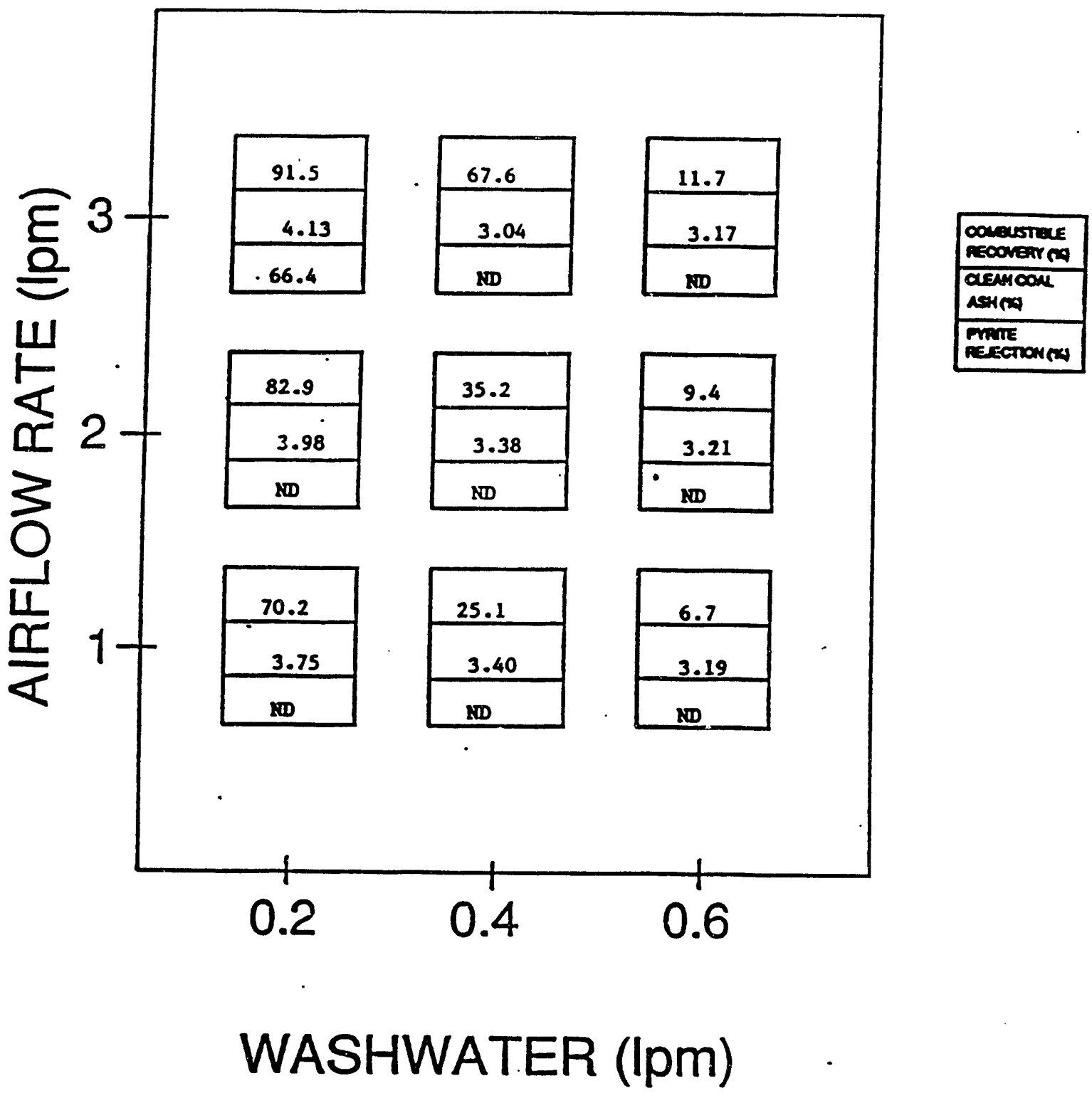

Figure B7. Effect of Airflow and Washwater Rates on Combustible Recovery, Clean Coal Ash and Pyrite Rejection for the Ziegler Slurry Using the Foam Jet Sparger and MIBC Frother

ND $=$ Not determined 


\section{PROJECT MANAGEMENT REPORT}

June 1, 1991 through August 31, 1991

Project Title:

Principal Investigator:

Co-Principal Investigator:

Project Monitor:
Recovery of Fine Coal from Waste Streams Using Advanced Column Flotation

John G. Groppo

Center for Applied Energy Research

University of Kentucky

Dr. 8. K. Parekh

Center for Applied Energy Research

University of Kentucky

Dr. Dan Banerjee

Center for Research on Sulfur in Coal

Comments 
SCHEDULE OF PROJECT MILESTONES

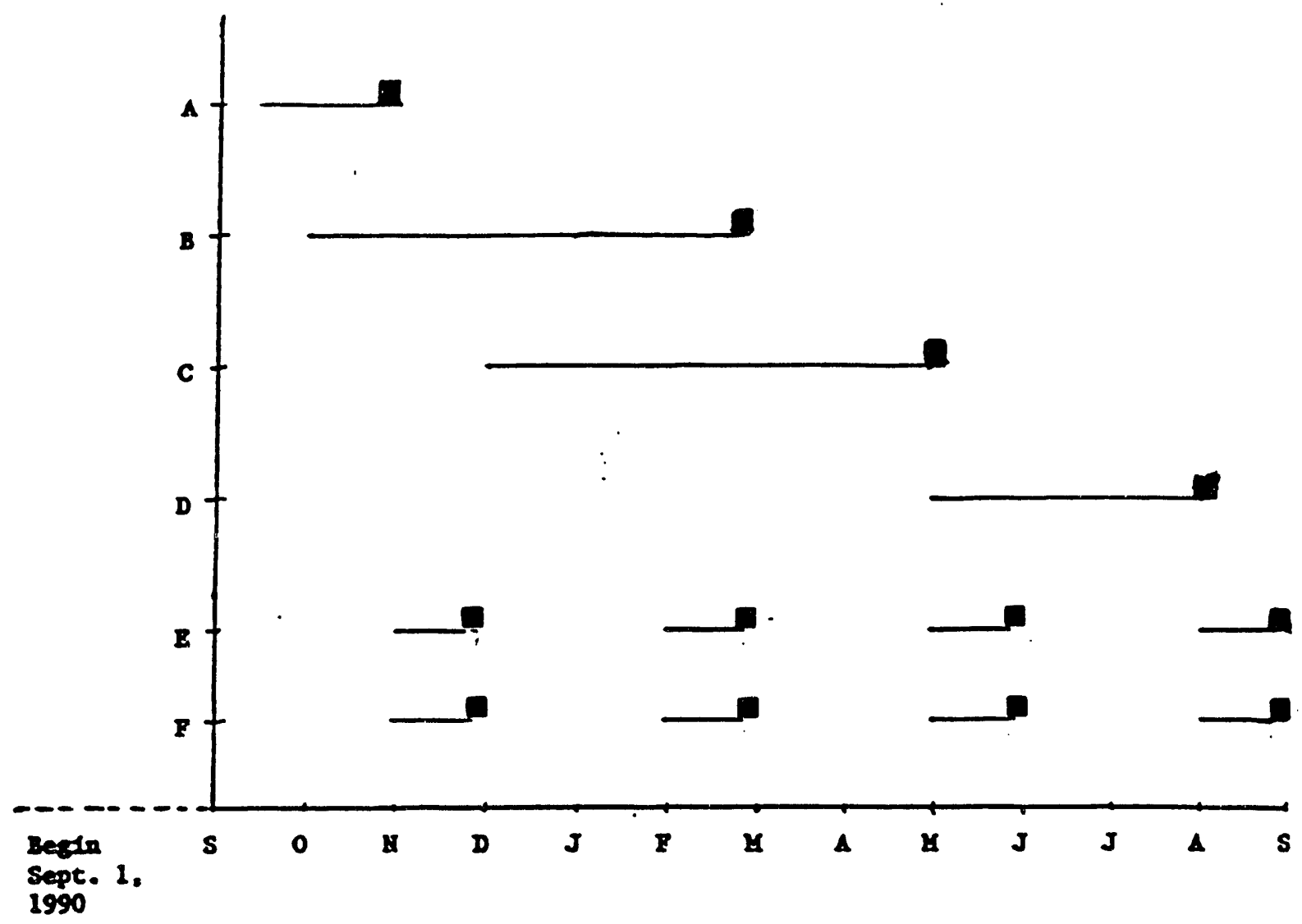

Hypothetical Milestones:

A. Acquisition and Characterization of Samples (Task 1)

B. Baseline Data Generation (Task 2)

C. 'Ken-Flote' Column Flotation Studies (Task 3)

D. 'Kenflote' Pilot Plant Studies (Task 4)

E. Toctnical Report prepared and submitted

F. Project Management reports prepared and submitted

Comments: ' 


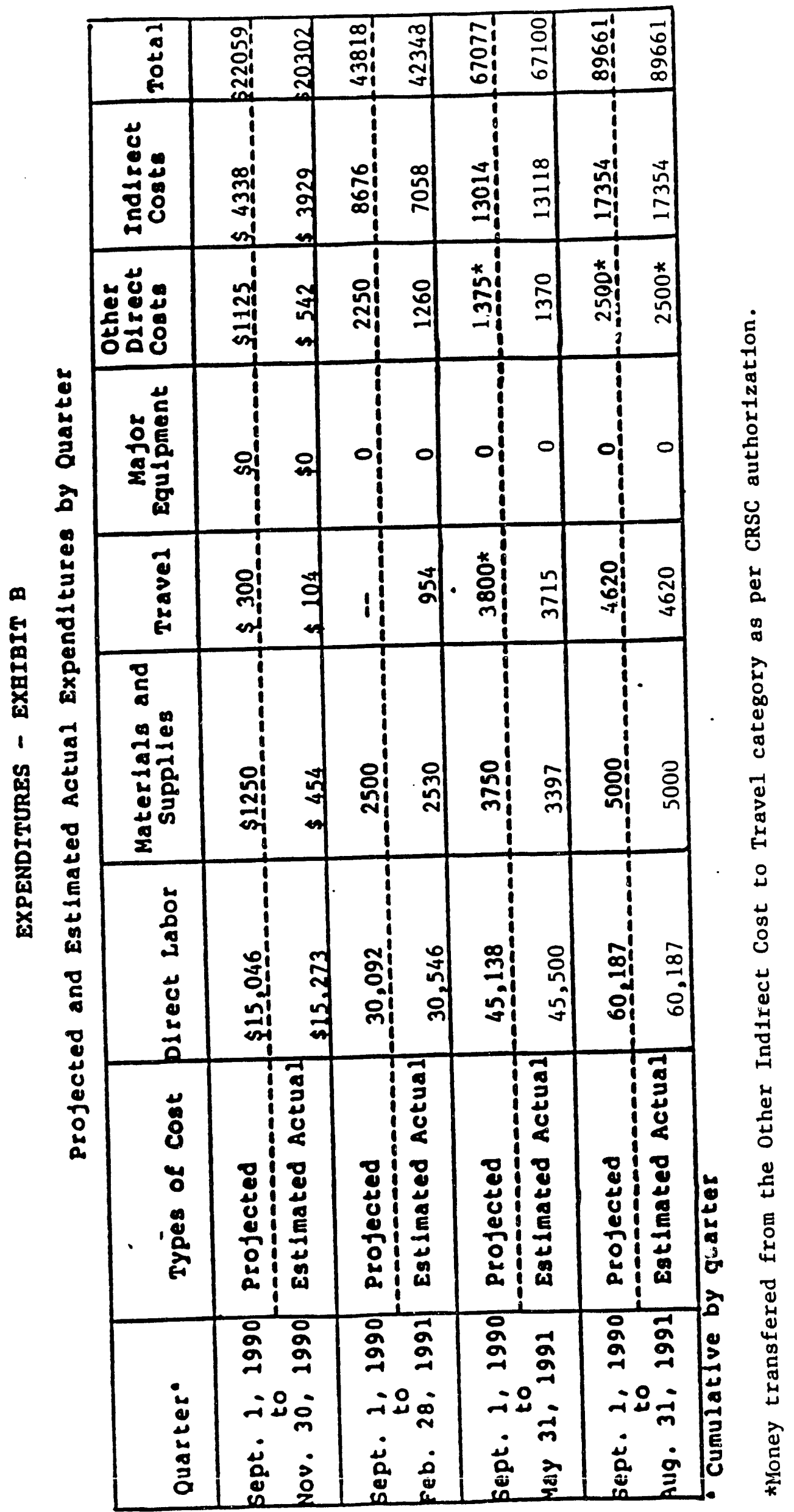




\section{COSTS BY QUARTER - EXHIBIT C}

RECOVERY OF FINE COAL FROM WASTE STREAMS

USING ADVANCED ' COLUMN FLOTATION

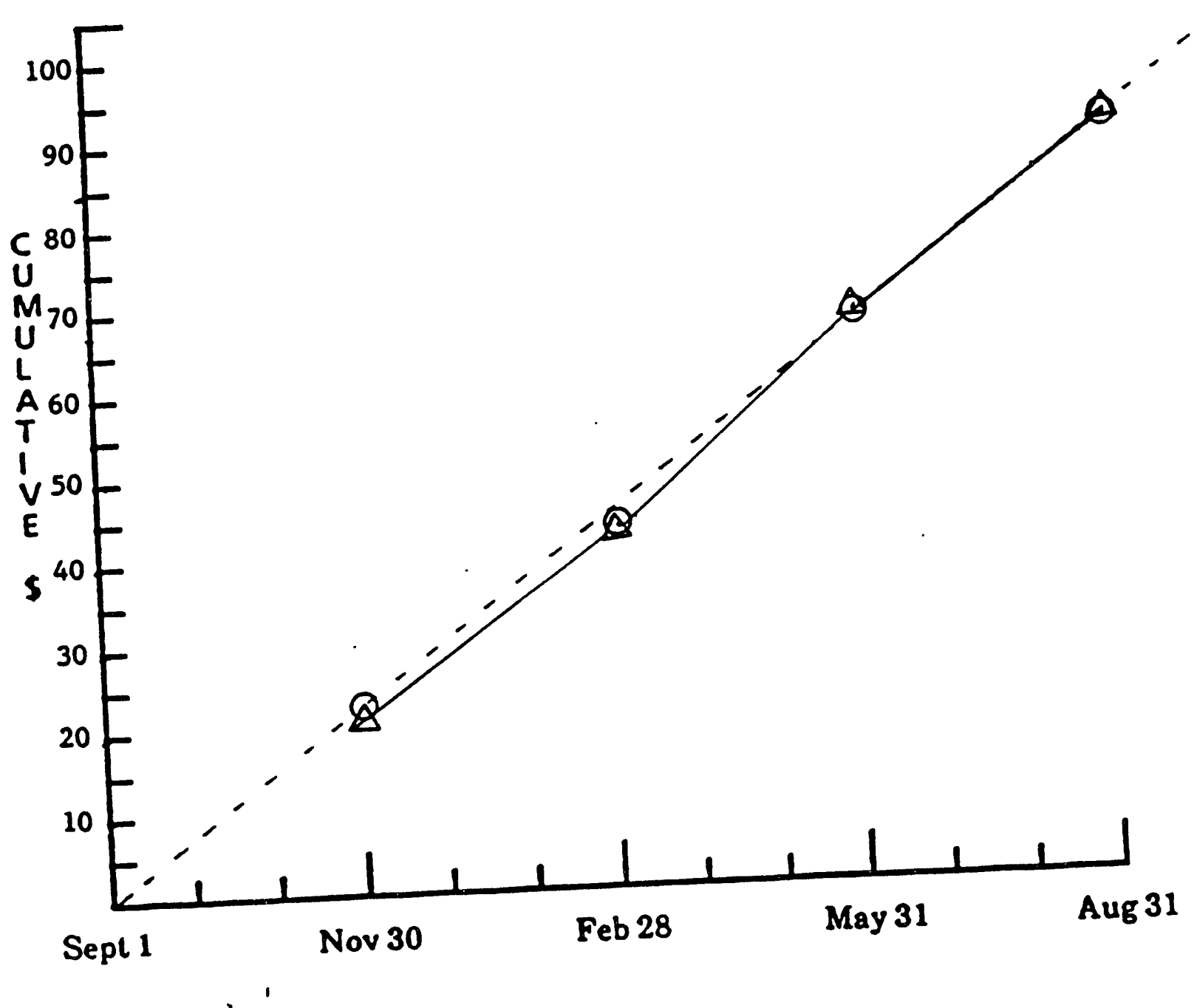

Months and Quarters

$0=$ Projected Expenditures

$\Delta=$ Actual Expenditures 

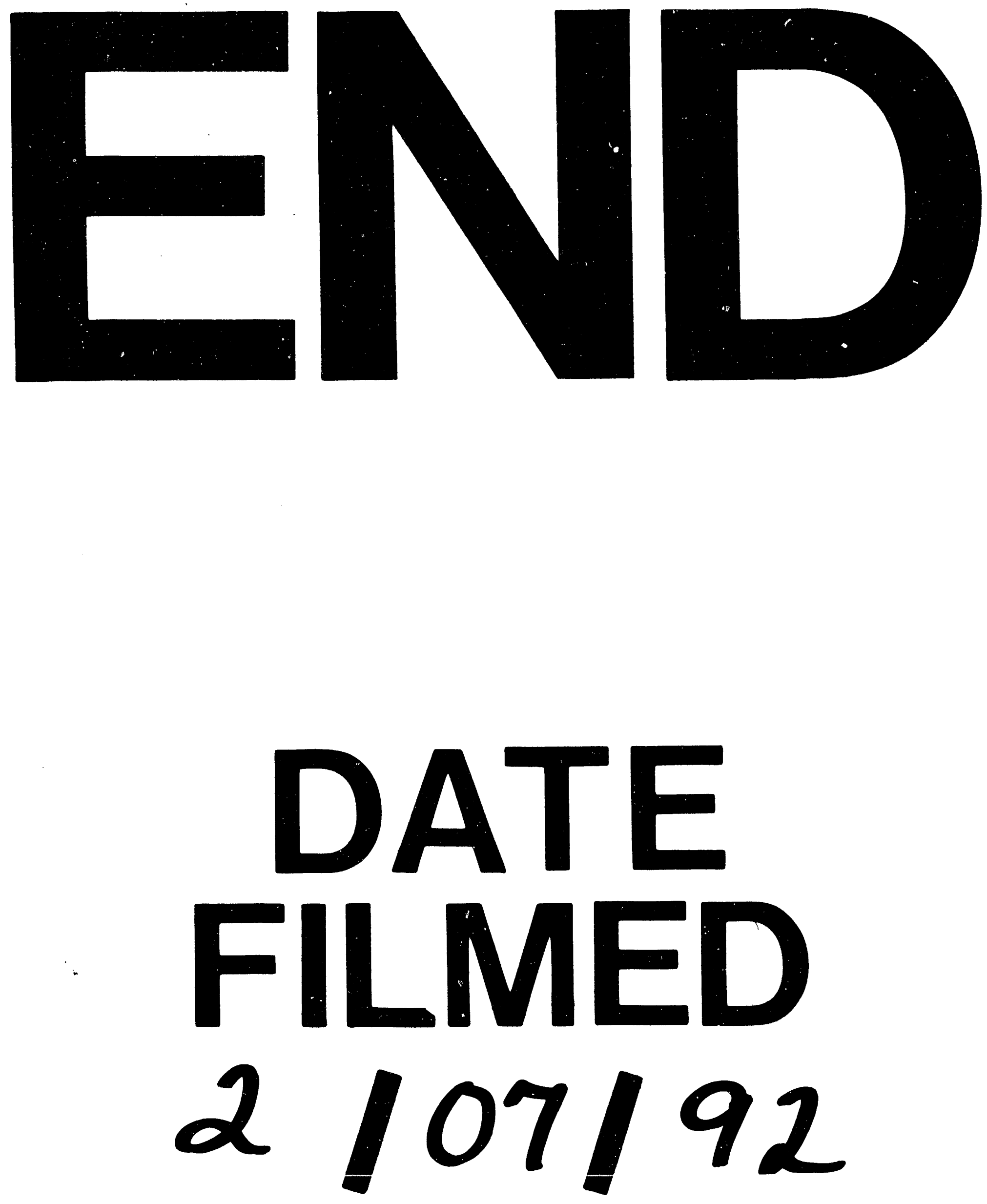

1 
